\title{
Solid-State Reactions and Dielectric Properties in the System Magnesia-Lime-Tin Oxide-Titania
}

\author{
L. W. Coughanour, R.' S. Roth, S. Marzullo, and F. E. Sennett
}

\begin{abstract}
A study has been made of solid-state reactions in the quaternary system $\mathrm{MgO}-\mathrm{CaO}-\mathrm{SnO}_{2}$ $\mathrm{TiO}_{2}$ and in its subordinate binary and ternary systems. Compatibility relations have been determined for each. Extensive solid-solution formation has been noted in the $\mathrm{SnO}_{2}-\mathrm{TiO}_{2}, \mathrm{MgO}-\mathrm{SnO}_{2}-\mathrm{TiO}_{2}, \mathrm{CaO}-\mathrm{SnO}_{2}-\mathrm{TiO}_{2}$, and $\mathrm{MgO}-\mathrm{CaO}-\mathrm{SnO}_{2}-\mathrm{TiO}_{2}$ systems. Little or no solid solution was observed in the other systems involved. One ternary compound, having the probable formula $2 \mathrm{MgO} \cdot \mathrm{SnO}_{2} \cdot \mathrm{TiO}_{2}$, has been observed. No quaternary compounds were detected.

A survey has been conducted of the effect of composition and temperature variations on the dielectric properties of specimens in some of these systems. Data are given for the values of $K$ and $O$ at 50 kilocycles per second, and at 1 and 20 megacycles per second. The changes in these values with changes in temperature have been studied at 1 megacycle per second.

Indexed X-ray powder patterns are listed for the compounds $\mathrm{CaO} \cdot \mathrm{TiO}_{2}, \mathrm{CaO} \cdot \mathrm{SnO}_{2}$, and $2 \mathrm{MgO} \cdot \mathrm{SnO}_{2} \cdot \mathrm{TiO}_{2}$. An unindexed pattern is given for the compound $2 \mathrm{CaO}^{\prime} \mathrm{SnO}_{2}$.
\end{abstract}

\section{Introduction!}

A partial survey of the $\mathrm{MgO}-\mathrm{CaO}-\mathrm{SnO}_{2}-\mathrm{TiO}_{2}$ system has been conducted as a part of a program of fundamental research on ceramic dielectrics. Limited portions of a few of the subsystems involved have been studied by previous investigators. The $\mathrm{MgO}-\mathrm{TiO}_{2}$ system has been reported on by Rieke and Ungewiss [1] ${ }^{2}$ and by Shelton et al. [2]. The properties of dielectrics in the $\mathrm{CaO}-\mathrm{TiO}_{2}$ system have been reported by Bunting et al. [3]. Dielectries in the $\mathrm{SnO}_{2}-\mathrm{TiO}_{2}$ system were studied by Schusterius [4] and by Verwey and Stevels [5]. Wainer [6] received a number of patents for dielectric bodies composed of alkaline-earth titanates and alkaline-earth stannates. Coffeen [7] has discussed the ceramic and dielectric properties of some individual stannates.

In the present work, the emphasis has been on the study of solid-state reactions occurring among the oxide components, and the effects of composition and temperature on dielectric properties, rather than on the development of ceramic dielectrics having specific properties or meeting any given set of specifications.

\section{Materials and Methods}

\subsection{Materials}

The following materials were used as sources of the component oxides in this study:

$\mathrm{MgO}$.- Reagent-grade magnesium carbonate of purity represented as 99.5 percent was the usual source material. However, in the fabrication of a few of the dielectric test specimens, a sample of periclase of 96.4-percent purity was used.

This study was sponsored by the Office of Ordnance Research, Department of the Army.

Figures in brackets indicate the literature references at the end of this paper.
$\mathrm{CaO}$.- Reagent-grade calcium carbonate of purity represented as 99.5 percent.

$\mathrm{TiO}_{2}$. - Spectrographic-grade titania of nominal purity over 99.9 percent was used in all specimens for the solid-state studies. In the preparation of some of the dielectric test specimens, a less highly purified grade of titania, designated TMO, was used. This grade of titania has a purity of about 98.7 percent. A commercial-grade calcium titanate was used in the preparation of a few dielectric test samples. This material has a nominal purity of 96.5 percent, the major impurities being $\mathrm{MgO}, \mathrm{SiO}_{2}$, and $\mathrm{Al}_{2} \mathrm{O}_{3}$.

$\mathrm{SnO}_{2}$.-Precipitated tin oxide of purity over 98.5 percent. Hydrated, precipitated magnesium stannate and calcium stannate were used as source materials in some cases. The calcium stannate was used wherever possible in dielectric test specimens. These materials both have a nominal purity over 99.5 percent.

\subsection{Sample Preparation}

Compositions to be prepared were designated on a mole-ratio basis, and calculations of the weight compositions were made to \pm 0.01 percent. No corrections were made for the percentage purity of the raw materials, although it is realized that dielectric properties may be affected by the presence of different kinds and amounts of impurities.

The raw materials in sufficient amounts to vield a 10-g sample were weighed to the nearest milligram and well mixed in the dry state. The samples were then mixed with about 5 percent of a 5 -percent starchsolution binder, and 1-in.-diameter disks were formed at a pressure of $5,000 \mathrm{lb} / \mathrm{in}^{2}$. The pressed disks were calcined for 4 hours at $1,000^{\circ}$ to $1,200^{\circ} \mathrm{C}$ on platinum foil in an oxidizing atmosphere. The calcined disks were pulverized, using a mullite mortar and pestle, and the samples were ready to be used either for the solid-state studies or for pressing into dielectric specimens. No chemical analyses were made after the firing. 


\subsection{Study of Solid-State Reactions}

In the study of solid-state reactions, a conventional type platinum-wound quench furnace was used. The temperature in the furnace was measured with a Pt-Pt-10-percent-Rh thermocouple and was controlled by a modified Roberts-type controller. The quenching technique was used in order that high-temperature solid solutions could be observed. For quench tests, a small amount of the prepared sample was placed in a platinum envelope, which was then suspended in the furnace. The test temperature ranged from $1,400^{\circ}$ to $1,550^{\circ}$ $\mathrm{C}$ and was maintained constant for a given length of time. After this reaction time, the sample was quenched, usually in air. In some cases, water or carbon tetrachloride was used as the quenching medium.

Alternatively, samples were heated to temperatures as high as $1,750^{\circ} \mathrm{C}$ and were cooled relatively slowly. The quenched or slowly cooled specimens were then analyzed by X-ray diffraction means and by petrographic methods.

These procedures are, in general, similar to those discussed by Foster [8].

\subsection{Preparation of Dielectric Test Specimens}

The prepared samples were moistened with about 5 percent of starch-solution binder, and disks about $1 / 8 \mathrm{in}$. thick and $1 / 2$ to $1 \frac{1 / 2}{\mathrm{in}}$. in diameter were formed at a pressure of 10,000 to $15,000 \mathrm{lb} / \mathrm{in} .^{2}$ The pressed disks were fired for $1 / 2$ to 1 hour on platinum foil in an oxidizing atmosphere. Maturing temperatures varied from $1,400^{\circ}$ to $1,750^{\circ} \mathrm{C}$, depending upon the composition and the raw materials used. For maturing temperatures up to $1,550^{\circ} \mathrm{C}$, a platinum-wound resistance furnace was used. Temperatures were measured with a Pt-Pt-10-percent-Rh thermocouple and were controlled by an automatic commercial controller-recorder. For maturing temperatures higher than $1,550^{\circ} \mathrm{C}$, an oxide-resistor furnace [9] was used. This furnace was manually controlled, and temperatures were measured with a calibrated optical pyrometer.

The fired specimens were then used to determine their absorption value, which is a convenient measure of the degree of maturity. The absorption was determined by placing the weighed disk in chemically pure carbon tetrachloride. The liquid was boiled for 5 hours and allowed to cool. The specimen was removed from the liquid, quickly surface dried, and weighed in a stoppered bottle. From the gain in weight, the equivalent water absorption was calculated. A specimen was considered to be properly matured when its equivalent water absorption was 0.1 percent or less of the dry weight.

Some compositions could not be fired to an impervious condition, and, in these cases, dielectric tests were performed on specimens having an absorption value greater than 0.1 percent.

\subsection{Determination of Dielectric Properties}

At frequencies between $50 \mathrm{kc} / \mathrm{s}$ and $20 \mathrm{Mc} / \mathrm{s}$ and at temperatures between $25^{\circ}$ and $250^{\circ} \mathrm{C}$, the dielec- tric constant $(K)$ and the $Q$-value (when greater than 10 , the $Q$-value is very nearly equal to the reciprocal of the power factor) were determined by measurements on a $Q$-meter. The test specimens were coated on each side with a silver paste and fired to $750^{\circ} \mathrm{C}$ to form silver electrodes 3 to 5 mils thick. The specimen was then cooled overnight. Preliminary determinations were made at a temperature of $25^{\circ} \pm 0.5^{\circ} \mathrm{C}$, and at a controlled relative humidity of 40 percent or less.

For measurements at temperatures greater than $25^{\circ} \mathrm{C}$, the specimens were placed on an electric hotplate and were connected to the Q-meter by 10-in. leads. The temperature was controlled by means of an adjustable autotransformer and was measured by means of a thermocouple inserted into a silvered ceramic disk adjacent to the specimen. Correction factors for the capacitance and inductance of the lead wires were applied.

For measurements in the temperature range between $-50^{\circ}$ and $25^{\circ} \mathrm{C}$, the specimens were placed in an insulated chamber cooled by dry ice. The temperature was controlled by a thermostat and was measured by means of a liquid-in-glass thermometer. The measurements were made at a frequency of 1 $\mathrm{Mc} / \mathrm{s}$ and were obtained by using a type $820 \mathrm{~A}$ twin- $\mathrm{T}$ impedance circuit combined with a model HRO-50T radio receiver. Corrections for the capacitance and inductance of the lead wires were applied.

For a given specimen, the reproducibility of measurements of dielectric constant is about \pm 3 percent, depending upon the dimensions and capacitance of the sample. For different specimens of the same gross composition, additional variations of $K$-values result from factors such as differences in firing schedules, purity of raw materials, etc.

\section{Results of Solid-State Reaction Studies}

\subsection{Binary Systems}

$$
\text { a. } \mathrm{MgO}-\mathrm{TiO}_{2}
$$

Three binary compounds are known to exist in the $\mathrm{MgO}-\mathrm{TiO}_{2}$ system [10]. They are $2 \mathrm{MgO} \cdot \mathrm{TiO}_{2}$, $\mathrm{MgO} \cdot \mathrm{TiO}_{2}$, and $\mathrm{MgO} \cdot 2 \mathrm{TiO}_{2}$. There is no solidsolution development in this system.

\section{b. $\mathrm{CaO}-\mathrm{TiO}_{2}$}

There are two binary compounds in this system [11]. They are $\mathrm{CaO} \cdot \mathrm{TiO}_{2}$ and $3 \mathrm{CaO} \cdot 2 \mathrm{TiO}_{2}$. The X-ray pattern for $3 \mathrm{CaO} \cdot 2 \mathrm{TiO}_{2}$ has been given in a previous publication [11].The indexed powder pattern for $\mathrm{CaO} \cdot \mathrm{TiO}_{2}$ is listed in table 1. This compound is an orthorhombic perovskite with the following pseudocubic-type parameters, as suggested by Megaw [12].

$$
\begin{aligned}
& a \cong \sqrt{2} \times \text { basic pseudocell }=5.381 \mathrm{~A}, \\
& b \cong 2 \times \text { basic pseudocell }=7.645 \mathrm{~A}, \\
& c \cong \sqrt{2} \times \text { basic pseudocell }=5.443 \mathrm{~A} .
\end{aligned}
$$


TABLE 1. X-ray diffraction pattern for the compound $\mathrm{CaO} \cdot \mathrm{TiO}_{2}$

\begin{tabular}{|c|c|c|c|c|c|c|c|}
\hline$h k l$ & $1 / d^{2}$ obs. & $1 / d^{2}$ calc. & R. I. ${ }^{a}$ & $h k l$ & $1 / d^{2}$ obs. & $1 / d^{2}$ calc. & R. I. a \\
\hline 101 & 0.068 & 0.068 & 30 & 333 & 7681 & .7686 & 7 \\
\hline 111 & .085 & .085 & 7 & 162 & .7840 & .7855 & 2 \\
\hline 002 & .135 & .135 & 51 & 044 & .8134 & .8138 & 18 \\
\hline 121 & .137 & .137 & $100+$ & 440 & .8260 & .8263 & 14 \\
\hline 200 & 138 & .138 & 70 & 070 & .8352 & .8384 & 5 \\
\hline 012 & .152 & .152 & 4 & 144 & .8480 & .8483 & 4 \\
\hline 102 & .169 & .170 & 4 & 170 & .8726 & .8729 & 3 \\
\hline 201 & .172 & .172 & 6 & 105 & .8776 & .8784 & 5 \\
\hline 112 & .186 & .187 & 5 & 115 & .8949 & .8955 & 7 \\
\hline 211 & .189 & .189 & 17 & 171 & .9065 & .9067 & 3 \\
\hline 022 & .203 & .203 & 12 & 125 & .9464 & .9468 & 12 \\
\hline 220 & 206 & .207 & 11 & 244 & 9518 & 9520 & 21 \\
\hline 131 & .222 & .222 & 6 & 163 & .9542 & .9543 & 21 \\
\hline 122 & .238 & .238 & 5 & 361 & .9606 & .9605 & 38 \\
\hline 221 & .240 & .240 & 4 & 521 & .9654 & .9655 & 40 \\
\hline 202 & .273 & .273 & 80 & 135 & 1. 0321 & 1. 0324 & 7 \\
\hline 040 & .274 & .274 & 78 & 404 & 1. 0925 & 1. 0926 & 8 \\
\hline 032 & .289 & .289 & 6 & 254 & 1.0955 & 1. 0959 & 6 \\
\hline 212 & .290 & .290 & 7 & 414 & 1. 1092 & 1. 1097 & 3 \\
\hline 132 & .323 & .324 & 2 & 145 & 1. 1520 & 1. 1521 & 5 \\
\hline 231 & .325 & .326 & 2 & 305 & 1. 1540 & 1. 1547 & 5 \\
\hline 103 & .338 & .338 & $\overline{5}$ & 541 & 1. 1705 & 1. 1709 & 4 \\
\hline 222 & .341 & .342 & 7 & 006 & 1. 2146 & 1. 2151 & 4 \\
\hline 141 & .342 & .342 & 5 & 325 & 1. 2229 & 1. 2231 & 16 \\
\hline 113 & .355 & .355 & 9 & $\left.\begin{array}{l}363 \\
016\end{array}\right\}$ & 1. 2310 & $\left\{\begin{array}{l}1.2306 \\
1.2322\end{array}\right\}$ & 29 \\
\hline 311 & .361 & .362 & 4 & & & & \\
\hline 123 & .407 & .407 & 29 & 523 & 1. 2357 & 1. 2356 & 28 \\
\hline 042 & .409 & 409 & 32 & 372 & 1. 2840 & 1. 2842 & 4 \\
\hline 240 & .412 & .412 & 34 & 155 & 1. 3059 & 1. 3061 & 6 \\
\hline 321 & .413 & .413 & 39 & $\begin{array}{l}335 \\
206\end{array}$ & $\begin{array}{l}\text { 1. } 3084 \\
\text { 1. } 3530\end{array}$ & $\begin{array}{l}\text { 1. } 3086 \\
1.3533\end{array}$ & $\begin{array}{l}5 \\
6\end{array}$ \\
\hline 241 & .445 & .446 & 3 & & & & \\
\hline 150 & .462 & .462 & 4 & $282\}$ & 1. 3668 & 1. 3681 & 16 \\
\hline 133 & .492 & .492 & 8 & $036\}$ & 1.3668 & & 92 \\
\hline 004 & .540 & .540 & 6 & 216 & 1. 3695 & 1. 3691 & 22 \\
\hline 242 & .547 & .547 & 29 & $\begin{array}{l}090 \\
226\end{array}$ & $\begin{array}{l}1.3852 \\
1.4218\end{array}$ & $\begin{array}{l}\text { 1. } 3859 \\
1.4217\end{array}$ & $\begin{array}{l}4 \\
5\end{array}$ \\
\hline 400 & .552 & .553 & 7 & 345 & 1. 4284 & 1. 4284 & 5 \\
\hline 104 & .574 & .575 & 3 & & & & \\
\hline 401 & .586 & .586 & 4 & 191 & 1. 4542 & 1. 4542 & 4 \\
\hline 152 & 597 & .597 & 7 & 046 & 1.4896 & 1.4889 & 4 \\
\hline 332 & 600 & .600 & 6 & 165 & 1. 4949 & 1. 4943 & 9 \\
\hline & & & & 561 & 1. 5143 & 1. 5131 & 13 \\
\hline 143 & .611 & .612 & 6 & 640 & 1. 5179 & 1. 5171 & 12 \\
\hline 313 & .631 & .632 & 5 & & & & \\
\hline 204 & .678 & .678 & 7 & 355 & 1. 5836 & 1. 5824 & 2 \\
\hline 323 & .683 & .683 & 12 & 326 & 1. 5957 & 1. 5944 & 3 \\
\hline 161 & 685 & .684 & 15 & 246 & 1. 6277 & 1. 6270 & 9 \\
\hline 402 & .688 & .688 & 10 & & & & \\
\hline 214 & .6942 & .6953 & 6 & & & & \\
\hline 252 & .7002 & .7009 & 5 & & & & \\
\hline 431 & 7396 & .7403 & 4 & & & & \\
\hline 153 & .7660 & .7661 & 7 & & & & \\
\hline
\end{tabular}

a $R$. I. is the intensity of diffraction peaks relative to the strongest peak.

\section{c. $\mathrm{MgO}-\mathrm{CaO}$}

This system has been shown to contain a simple eutectic, with no compounds or solid solutions [13].

\section{d. $\mathrm{MgO}-\mathrm{SnO}_{2}$}

Only a brief study of this system was made, in order to verify previously published data [14].

The $\mathrm{MgO}-\mathrm{SnO}_{2}$ compositions studied are listed in table 2 , together with the results obtained. X-ray and petrographic examination of these fired specimens indicated the existence of two binary compounds. They are $2 \mathrm{MgO} \cdot \mathrm{SnO}_{\text {s }}$, which is thermally stable at temperatures as high as $1,550^{\circ} \mathrm{C}$, and $\mathrm{MgO} \cdot \mathrm{SnO}_{2}$, which decomposes into $2 \mathrm{MgO} \cdot \mathrm{SnO}_{2}$ and $\mathrm{SnO}_{2}$ between $800^{\circ}$ and $1,000^{\circ}$ C. The compound $2 \mathrm{MgO} \cdot \mathrm{SnO}_{2}$ has a cubic spinel-type structure with $a=8.645 \mathrm{~A}$ and with an index of refraction equal to approximately 1.82 . These results are in agreement with the work of Tanaka [14], but are somewhat at variance with the results of Coffeen [7], who reported the compound $\mathrm{MgO} \cdot \mathrm{SnO}_{2}$ to be thermally stable.

TABLE 2. Results of X-ray examination of specimens in the $\mathrm{MgO}-\mathrm{SnO}_{2}$ system

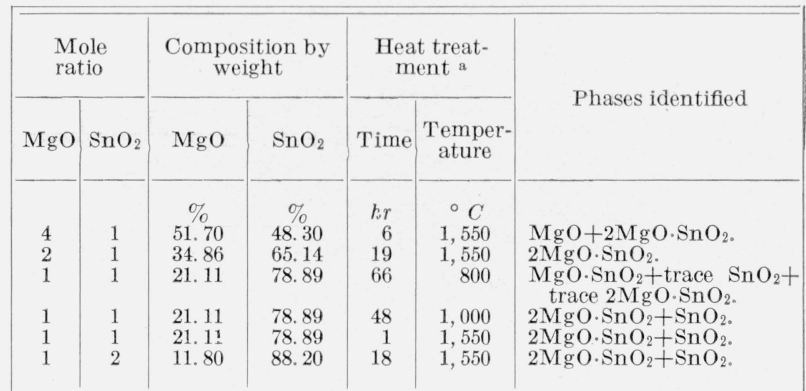

a Each sample had been previously ealcined for 4 hours at $1,100^{\circ} \mathrm{C}$. The specimens were quenched in air from the temperature indicated.

$$
\text { e. } \mathrm{CaO}-\mathrm{SnO}_{2}
$$

Two compounds were noted in this system. They are $\mathrm{CaO} \cdot \mathrm{SnO}_{2}$, which has an orthorhombic perovskite structure, and $2 \mathrm{CaO} \cdot \mathrm{SnO}_{2}$. These results agree with the findings of Tanaka [15]. An indexed powder pattern for the compound $\mathrm{CaO} \cdot \mathrm{SnO}_{2}$ is given 1 in table 3. The parameters of $\mathrm{CaO} \cdot \mathrm{SnO}_{2}$ are:

$$
\begin{aligned}
& a \simeq \sqrt{2} \times \text { basic pseudocell }=5.518 \mathrm{~A}, \\
& b \simeq 2 \times \text { basic pseudocell }=7.884 \mathrm{~A}, \\
& c \simeq \sqrt{2} \times \text { basic pseudocell }=5.664 \mathrm{~A} .
\end{aligned}
$$

\begin{tabular}{|c|c|c|c|c|c|c|c|}
\hline$h k l$ & $\begin{array}{l}1 / d^{2} \\
\text { obs. }\end{array}$ & $\begin{array}{l}1 / d^{2} \\
\text { calc. }\end{array}$ & R. I. ${ }^{a}$ & $h k l$ & $\begin{array}{l}1 / d^{2} \\
\text { obs. }\end{array}$ & $\begin{array}{l}1 / d^{2} \\
\text { calc. }\end{array}$ & R. I. a \\
\hline 101 & 0.064 & 0.064 & $100+$ & 153 & & 7156 & \\
\hline 111 & .080 & .080 & 7 & 044 & .7561 & .7562 & 6 \\
\hline 002 & .125 & .125 & 63 & 440 & .7829 & .7830 & 5 \\
\hline 121 & .129 & .128 & $100++$ & 105 & .8125 & .8121 & 3 \\
\hline 200 & .131 & .131 & 56 & 343 & 8343 & 8336 & 6 \\
\hline 201 & .163 & .163 & 4 & 262 & & .8352 & $\begin{array}{l}0 \\
7\end{array}$ \\
\hline 211 & .178 & .179 & 7 & 125 & .8774 & $\begin{array}{l}.8352 \\
.8765\end{array}$ & 4 \\
\hline 022 & 189 & .189 & 8 & 244 & .8878 & .8875 & 7 \\
\hline 220 & .196 & .196 & 8 & 163 & .8925 & .8926 & 9 \\
\hline 131 & .209 & .209 & 4 & & & & \\
\hline & & & & $\begin{array}{l}361 \\
442\end{array}$ & $\begin{array}{r}9065 \\
9079\end{array}$ & $\begin{array}{l}9060 \\
9077\end{array}$ & $\begin{array}{r}9 \\
12\end{array}$ \\
\hline $\begin{array}{l}122 \\
202\end{array}$ & .222 & $\begin{array}{l}222 \\
256\end{array}$ & $\begin{array}{r}2 \\
61\end{array}$ & $\begin{array}{l}442 \\
521\end{array}$ & $\begin{array}{r}9079 \\
9168\end{array}$ & $\begin{array}{l}.9077 \\
9167\end{array}$ & $\begin{array}{r}12 \\
8\end{array}$ \\
\hline 040 & $\begin{array}{l}.200 \\
.257\end{array}$ & .257 & 61 & 404 & 1. 0248 & 1.0243 & $\begin{array}{l}0 \\
3\end{array}$ \\
\hline 212 & .272 & .272 & 4 & 080 & 1.0296 & 1.0296 & 4 \\
\hline 103 & .313 & .313 & 17 & & & & \\
\hline $141 / 222$ & & & & 145 & 1.0701 & 1.0695 & 4 \\
\hline $\begin{array}{c}141 / 222 \\
301\end{array}$ & $\begin{array}{r}.321 \\
327\end{array}$ & $\begin{array}{l}.321 \\
327\end{array}$ & $\begin{array}{r}37 \\
9\end{array}$ & 305 & 1. 0752 & 1.0749 & 5 \\
\hline 123 & $\begin{array}{l}.327 \\
.378\end{array}$ & $\begin{array}{l}.528 \\
.378\end{array}$ & $\begin{array}{l}9 \\
37\end{array}$ & $\begin{array}{l}424 \\
181\end{array}$ & $\begin{array}{l}1.0894 \\
1.0941\end{array}$ & $\begin{array}{l}1.0887 \\
1.0937\end{array}$ & $\begin{array}{l}4 \\
5\end{array}$ \\
\hline 042 & .382 & .382 & 26 & 325 & 1. 1397 & 1. 1393 & $\begin{array}{l}0 \\
5\end{array}$ \\
\hline 240 & 389 & 389 & 25 & & & & \\
\hline & & & & 363 & 1. 1553 & 1.1553 & 8 \\
\hline 321 & .391 & .391 & 46 & 280 & 1. 1612 & 1. 1610 & 9 \\
\hline 133 & .459 & .458 & 2 & 523 & 1. 1666 & 1. 1661 & 8 \\
\hline 004 & .499 & .499 & 7 & 182 & 1. 1870 & 1. 1872 & 6 \\
\hline 242 & .514 & .513 & 22 & 264 & 1. 2105 & 1. 2090 & 5 \\
\hline 400 & .526 & .526 & 6 & & & & \\
\hline 024 & .563 & .563 & 6 & $\begin{array}{l}155 \\
444\end{array}$ & $\begin{array}{l}\text { 1. } 2159 \\
\text { 1. } 2825\end{array}$ & $\begin{array}{l}\text { 1. } 2143 \\
\text { 1. } 2817\end{array}$ & $\begin{array}{l}5 \\
5\end{array}$ \\
\hline 143 & .571 & .571 & 10 & $\begin{array}{l}444 \\
282\end{array}$ & $\begin{array}{l}\text { 1. } 28640 \\
\text { 1. } 284\end{array}$ & $\begin{array}{l}\text { 1. } 2817 \\
\text { 1. } 2857\end{array}$ & $\begin{array}{l}5 \\
5\end{array}$ \\
\hline 060 & .579 & .579 & 4 & 226 & 1. 3184 & 1. 3179 & 4 \\
\hline 341 & .584 & .584 & 5 & 345 & 1. 3325 & 1. 3323 & 3 \\
\hline 420 & .590 & .590 & 4 & & & & \\
\hline 204 & .630 & .630 & 5 & $\begin{array}{l}143 \\
471\end{array}$ & 1. 3436 & $\begin{array}{l}\text { 1. } 3430 \\
1.3450\end{array}$ & 3 \\
\hline 323 & .641 & .641 & 11 & 165 & 1. 3919 & 1. 3913 & 4 \\
\hline 161 & .643 & .643 & 16 & 561 & 1.4325 & 1. 4315 & 8 \\
\hline 402 & .650 & .650 & 6 & 316 & -..... & 1. 4339 & $\ldots$ \\
\hline 224 & .695 & .694 & 6 & 246 & 1. 5119 & 1.5110 & 3 \\
\hline 422 & .7151 & .7146 & 6 & 642 & 1. 5649 & 1. 5646 & $\begin{array}{l}0 \\
5\end{array}$ \\
\hline
\end{tabular}

TABLE 3. X-ray diffraction pattern for the compound $\mathrm{CaO} \cdot \mathrm{SnO}_{2}$

a R.I. is the intensity of diffraction peaks relative to the strongest peak. 
The structure of the $2: 1$ compound has not been determined. Its X-ray diffraction pattern is listed in table 4.

The compositions studied in the $\mathrm{CaO}-\mathrm{SnO}_{2}$ system and the results obtained are given in table 5 .

TABLE 4. X-ray diffraction pattern of the compound $2 \mathrm{CaO} \cdot \mathrm{SnO}_{2}$

\begin{tabular}{|c|c|c|c|c|c|}
\hline $2 \theta$ & $d$ & R. I. a & $2 \theta$ & $d$ & R. I. a \\
\hline 17. 93 & 4. 9 & 100 & 87.09 & 1. 118 & 1 \\
\hline 18. 29 & 4. 8 & 18 & 88.18 & 1. 107 & .5 \\
\hline 24.00 & 3. 70 & 5 & 89.96 & 1. 089 & .5 \\
\hline 27. 31 & 3. 26 & 2 & 90.50 & 1. 085 & 1 \\
\hline 31.08 & 2.88 & 25 & $\begin{array}{l}91.06 \\
92.36\end{array}$ & $\begin{array}{l}1.079 \\
1.068\end{array}$ & $\begin{array}{l}2 \\
5\end{array}$ \\
\hline 31.74 & 2. 82 & 77 & & & \\
\hline 32.87 & 2. 72 & 80 & 92.80 & 1. 064 & 7 \\
\hline 33.04 & 2. 71 & 32 & 92. 91 & 1. 063 & 6 \\
\hline 36. 29 & 2. 47 & 7 & 93.19 & 1. 060 & 6 \\
\hline 37.04 & 2. 42 & 10 & $\begin{array}{l}93.48 \\
93.90\end{array}$ & $\begin{array}{l}\text { 1. } 058 \\
\text { 1. } 054\end{array}$ & $\begin{array}{l}6 \\
5\end{array}$ \\
\hline 40.33 & 2. 23 & 12 & & & \\
\hline 41.81 & 2. 16 & 10 & 94. 71 & 1. 047 & 2 \\
\hline 42.88 & 2. 11 & 16 & 95.61 & 1. 039 & 3 \\
\hline 45.97 & 1. 97 & 45 & 96. 90 & 1. 029 & 5 \\
\hline 46.62 & 1. 95 & 11 & $\begin{array}{l}97.92 \\
98.94\end{array}$ & $\begin{array}{l}1.021 \\
1.013\end{array}$ & $\begin{array}{l}3 \\
1\end{array}$ \\
\hline 48.34 & 1. 88 & 7 & & & \\
\hline 49. 09 & 1.85 & 10 & 99.67 & 1. 008 & 1 \\
\hline 49. 36 & 1. 84 & 2 & 101.18 & 0. 9969 & 4 \\
\hline 49.54 & 1. 84 & 3 & 101. 56 & .9942 & 3 \\
\hline 50.83 & 1. 79 & 2 & $\begin{array}{l}102.13 \\
102.66\end{array}$ & $\begin{array}{r}.9902 \\
.9865\end{array}$ & $\begin{array}{l}3 \\
3\end{array}$ \\
\hline 51.17 & 1. 78 & 7 & & & \\
\hline 55. 67 & 1. 65 & 10 & 105.09 & .9703 & 0.5 \\
\hline 56. 28 & 1. 63 & 14 & 107.56 & .9543 & .5 \\
\hline 56. 39 & 1. 63 & 21 & 108. 74 & .9477 & 1 \\
\hline 56.89 & 1. 62 & 7 & $\begin{array}{l}109.59 \\
109.90\end{array}$ & $\begin{array}{l}.9427 \\
.9409\end{array}$ & $\begin{array}{l}2 \\
4\end{array}$ \\
\hline 57.06 & 1. 61 & 15 & 110.06 & .9399 & 4 \\
\hline 57.47 & 1. 60 & 22 & 110.57 & .9371 & 8 \\
\hline 58.94 & 1. 57 & 3 & 111. 82 & $\begin{array}{r}9301 \\
0973\end{array}$ & $\begin{array}{l}2 \\
3\end{array}$ \\
\hline $\begin{array}{l}59.56 \\
61.59\end{array}$ & $\begin{array}{l}1.55 \\
1.50\end{array}$ & $\begin{array}{l}7 \\
2\end{array}$ & $\begin{array}{l}112.32 \\
112.64\end{array}$ & $\begin{array}{l}.9273 \\
.9256\end{array}$ & $\begin{array}{l}3 \\
4\end{array}$ \\
\hline 63.08 & 1.47 & 9 & 113. 66 & .9202 & 5 \\
\hline 64.20 & 1. 45 & 3 & 115.87 & .9089 & 2 \\
\hline 64.77 & 1. 44 & 3 & 116.99 & .9034 & 3 \\
\hline 65.54 & 1. 42 & 3 & 118. 14 & .8979 & 1 \\
\hline 65.68 & 1. 42 & 6 & 119.43 & .8919 & 3 \\
\hline 66.05 & 1. 41 & 14 & 120.09 & .8890 & 3 \\
\hline 66. 23 & 1. 41 & 13 & 120.92 & .8853 & 2 \\
\hline 67.88 & 1. 38 & 8 & 122.75 & .8775 & 0.5 \\
\hline 68.74 & 1. 36 & 4 & 125.00 & .8684 & .5 \\
\hline 69.23 & 1. 36 & 4 & 127.09 & .8603 & 2 \\
\hline 69. 70 & 1. 35 & 4 & 128.65 & .8546 & 4 \\
\hline 71.01 & 1. 33 & 3 & 129.59 & .8513 & 2 \\
\hline 71.11 & 1. 32 & 3 & 130.95 & .8466 & 4 \\
\hline 72.33 & 1. 31 & 2 & 132. 24 & .8424 & 5 \\
\hline 73.00 & 1. 29 & 2 & 134.82 & .8343 & 2 \\
\hline 74. 36 & 1. 27 & 4 & 138.10 & .8248 & 0.5 \\
\hline 75.43 & 1. 26 & 5 & 140. 26 & .8190 & 2 \\
\hline 76. 36 & 1. 25 & 3 & 141.10 & .8169 & 3 \\
\hline 76.98 & 1. 24 & 3 & 142.02 & .8146 & 5 \\
\hline 77.24 & 1. 23 & 4 & 143.86 & .8102 & 2 \\
\hline 77.83 & 1. 23 & 3 & 145.11 & .8074 & 3 \\
\hline 78.10 & 1. 22 & 3 & 148.10 & .8011 & 3 \\
\hline 79.47 & 1. 21 & 2 & 148.82 & .7997 & 4 \\
\hline 82.64 & 1. 167 & 2 & 151. 69 & .7944 & 2 \\
\hline 83.10 & 1. 161 & 5 & 155.42 & .7883 & 1 \\
\hline 83.44 & 1. 157 & 5 & 157.37 & .7855 & 1 \\
\hline 84.13 & 1. 149 & 4 & 158. 23 & .7844 & 3 \\
\hline 84. 74 & 1. 143 & 4 & 160.07 & .7821 & 2 \\
\hline 85.25 & 1. 137 & 4 & 162.00 & .7799 & 3 \\
\hline 86.53 & 1. 124 & 3 & 163.58 & .7782 & 4 \\
\hline
\end{tabular}

a R. I. is the intensity of diffraction peaks relative to the strongest peak.
TABLE 5. Results of X-ray examination of specimens in the $\mathrm{CaO}-\mathrm{SnO}_{2}$ system

\begin{tabular}{|c|c|c|c|c|c|c|}
\hline \multicolumn{2}{|c|}{ Mole ratio } & \multicolumn{2}{|c|}{$\begin{array}{l}\text { Composition by } \\
\text { weight }\end{array}$} & \multicolumn{2}{|c|}{$\begin{array}{c}\text { Heat } \\
\text { treatment a }\end{array}$} & \multirow{2}{*}{ Phases identified } \\
\hline $\mathrm{CaO}$ & $\mathrm{SnO}_{2}$ & $\mathrm{CaO}$ & $\mathrm{SnO}_{2}$ & Time & $\begin{array}{l}\text { Tem- } \\
\text { perature }\end{array}$ & \\
\hline $\begin{array}{l}4 \\
5 \\
2\end{array}$ & $\begin{array}{l}1 \\
2 \\
1\end{array}$ & $\begin{array}{c}\% \\
59.82 \\
48.19 \\
42.67\end{array}$ & $\begin{array}{c}\% \\
40.18 \\
51.80 \\
57.33\end{array}$ & $\begin{array}{r}h r \\
18 \\
40 \\
3\end{array}$ & $\begin{array}{c}{ }^{\circ} C \\
1,400 \\
1,300 \\
1,550\end{array}$ & $\begin{array}{l}\mathrm{CaO}+2 \mathrm{CaO} \cdot \mathrm{SnO}_{2} . \\
\mathrm{CaO}+2 \mathrm{CaO} \cdot \mathrm{SnO}_{2} . \\
2 \mathrm{CaO} \cdot \mathrm{SnO} \mathrm{S}_{2}+\mathrm{small} \\
\mathrm{amount} \mathrm{CaO} \cdot \mathrm{SnO}_{2} . \\
\mathrm{CaO} \cdot \mathrm{SnO}_{2} . \\
\mathrm{CaO} \cdot \mathrm{SnO}_{2}+\mathrm{SnO}_{2} . \\
\mathrm{CaO} \cdot \mathrm{SnO}_{2}+\mathrm{SnO}_{2} .\end{array}$ \\
\hline
\end{tabular}

a Each sample had been previously calcined for 4 hours at $1,200^{\circ} \mathrm{C}$. All samples were quenched in air from the temperature indicated.

\section{f. $\mathrm{SnO}_{2}-\mathrm{TiO}_{2}$}

This system was found to consist, at $1,550^{\circ} \mathrm{C}$, of a continuous solid-solution series. These solid solutions may be effectively stabilized by quenching in air. Slow cooling, however, results in an unmixing reaction in the compositions in the central portion of the system. The results of the tests are given in table 6 . These results are in general agreement with those of Schusterius [4].

TABle 6. X-ray data for the $\mathrm{SnO}_{2}-\mathrm{TiO}_{2}$ system ${ }^{\text {a }}$

\begin{tabular}{|c|c|c|c|c|c|c|}
\hline \multicolumn{2}{|c|}{ Mole ratio } & \multicolumn{2}{|c|}{$\begin{array}{c}\text { Composition by } \\
\text { weight }\end{array}$} & \multirow{2}{*}{$a$} & \multirow{2}{*}{$c$} & \multirow{2}{*}{$c / a$ ratio } \\
\hline $\mathrm{SnO}_{2}$ & $\mathrm{TiO}_{2}$ & $\mathrm{SnO}_{2}$ & $\mathrm{TiO}_{2}$ & & & \\
\hline $\begin{array}{l}1 \\
4 \\
2 \\
1 \\
1 \\
1 \\
0\end{array}$ & $\begin{array}{r}0 \\
1 \\
\text { b } 1 \\
\text { b } 1 \\
\text { b } 2 \\
4 \\
1 \\
1\end{array}$ & $\begin{array}{c}\% \\
100 \\
88.30 \\
79.05 \\
65.35 \\
48.54 \\
32.04 \\
0\end{array}$ & $\begin{array}{l}\% \\
0 \\
11.70 \\
20.96 \\
34.65 \\
51.47 \\
67.96 \\
100\end{array}$ & $\begin{array}{c}\text { A } \\
\text { 4. } 738 \\
\text { 4. } 710 \\
4.692 \\
\text { 4. } 664 \\
\text { 4. } 644 \\
\text { 4. } 624 \\
4.592\end{array}$ & $\begin{array}{c}A \\
3.185 \\
3.143 \\
3.130 \\
3.065 \\
3.029 \\
3.001 \\
2.959\end{array}$ & $\begin{array}{r}0.6772 \\
.6673 \\
.6672 \\
.6572 \\
.6522 \\
.6491 \\
.6444\end{array}$ \\
\hline
\end{tabular}

a Each sample had been fired to $1,550^{\circ} \mathrm{C}$ for at least 3 hours before cooling and conducting a petrographic and $\mathrm{X}$-ray examination.

b An unmixing reaction occurred on slow cooling of these samples. The unmixing was prevented by quenching in air from the high temperature.

\subsection{Ternary Systems}

\section{a. $\mathrm{MgO}-\mathrm{CaO}-\mathrm{TiO}_{2}$}

A total of 42 compositions were prepared in this system for studies of phase relations and of dielectric properties. Of these, 18 selected samples were used in the determination of the compatability relations. These samples were subjected to suitable heat treatment and subsequently analyzed by X-ray or petrographic methods. The results of these tests are given in table 7 , and the composition triangles are shown in figure 1 . Of the various possible binary joins in the ternary system, the following exist in the subsolidus diagram: ${ }^{3}$

$\mathrm{MT}_{2}$-CT, MT-CT, $\mathrm{M}_{2} \mathrm{~T}-\mathrm{CT}, \mathrm{MgO}-\mathrm{CT}$, and

$$
\mathrm{MgO}-\mathrm{C}_{3} \mathrm{~T}_{2} \text {. }
$$

${ }^{3} \mathrm{M}=\mathrm{MgO}, \mathrm{C}=\mathrm{CaO}, \mathrm{T}=\mathrm{TiO}_{2}, \mathrm{~S}=\mathrm{SnO}_{2}$. Thus, the formula $3 \mathrm{CaO} \cdot 2 \mathrm{TiO}$ is shortened to $\mathrm{C}_{3} \mathrm{~T}_{2}$ 
It should be noted that the results (table 8 ) indicate little or no solid-solution formation in this system, with the probable exception of the areas adjacent to the compound $\mathrm{C}_{3} \mathrm{~T}_{2}$. This compound was found to undergo marked changes in structure with only very small quantities of impurities entering its lattice. These changes are discussed in a later portion of this report.

TABLE 7. Results of X-ray and petrographic study of selected compositions in the system $\mathrm{MgO}-\mathrm{CaO}-\mathrm{TiO}_{2}$

\begin{tabular}{|c|c|c|c|c|}
\hline \multirow{2}{*}{$\begin{array}{c}\text { Mole ratio } \\
\text { M:C:T }\end{array}$} & \multirow{2}{*}{$\begin{array}{l}\text { Binary join or } \\
\text { ternary field }\end{array}$} & \multicolumn{2}{|c|}{ Heat treatment } & \multirow{2}{*}{ Phasesidentified } \\
\hline & & Time & $\begin{array}{l}\text { Temper- } \\
\text { ature }\end{array}$ & \\
\hline $\begin{array}{l}4: 1: 9 \ldots \\
1: 4: 6 \ldots \\
4: 1: 5 \ldots \\
1: 2: 3 \ldots \\
1: 5: 6 \ldots\end{array}$ & $\begin{array}{l}\mathrm{MT}_{2}-\mathrm{CT} \\
\mathrm{MT}-\mathrm{CT} \\
\mathrm{do}\end{array}$ & $\begin{array}{l}h r \\
1 \\
1 \\
1 \\
4 \\
1\end{array}$ & $\begin{array}{r}{ }^{\circ} \mathrm{C} \\
\mathrm{a} 1,550 \\
1,550 \\
1,550 \\
\mathrm{~b} 1,475 \\
1,550\end{array}$ & $\begin{array}{c}\mathrm{MT}_{2}+\mathrm{CT} . \\
\text { Do. } \\
\mathrm{MT}+\mathrm{CT} . \\
\text { Do. } \\
\text { Do. }\end{array}$ \\
\hline $\begin{array}{l}6: 1: 4 \ldots \\
2: 7: 8 \ldots \\
1: 3: 3 \ldots \\
18: 3: 2 \ldots \\
1: 3: 2 \\
2: 27: 18 \\
\end{array}$ & $\begin{array}{l}\mathrm{M}_{2} \mathrm{~T}-\mathrm{CT} \\
\mathrm{MgO}-\mathrm{C} \\
\mathrm{MgO}-\mathrm{C}_{3} \mathrm{~T}_{2} \\
\mathrm{do}\end{array}$ & $\begin{array}{l}1 \\
1 \\
1 \\
2.5 \\
1 \\
2\end{array}$ & $\begin{array}{c}1,550 \\
1,550 \\
1,740 \\
1,550 \\
1,645 \\
>1,600\end{array}$ & $\begin{array}{c}\mathrm{M}_{2} \mathrm{~T}+\mathrm{CT} \\
\text { Do. } \\
\mathrm{MgO}+\mathrm{CT} \\
\text { c } \mathrm{MgO}+\mathrm{C}_{3} \dot{\mathrm{T}}_{2} \\
\text { Do. } \\
\mathrm{C}_{3} \mathrm{~T}_{2}+\text { trace } \mathrm{CaO}\end{array}$ \\
\hline $\begin{array}{l}1: 1: 5 \\
3: 2: 6 \ldots \\
4: 1: 4 \ldots \\
4: 1: 2 \ldots \\
1: 5: 4 \ldots \\
2: 2: 1 \ldots \\
2: 3: 1 \ldots \\
\end{array}$ & $\begin{array}{l}\mathrm{MT}_{2}-\mathrm{CT}-\mathrm{TiO}_{2} \\
\mathrm{MT}_{2}-\mathrm{MT}-\mathrm{CT} \\
\mathrm{MT}-\mathrm{M}_{2} \mathrm{~T}-\mathrm{CT} \\
\mathrm{MgO}-\mathrm{M}_{2} \mathrm{~T}-\mathrm{CT} \\
\mathrm{MgO}-\mathrm{CT}-\mathrm{C}_{3} \mathrm{~T}_{2} \\
\mathrm{MgO}-\mathrm{CaO}-\mathrm{C}_{3} \mathrm{~T}_{2} \\
\quad \text { do }\end{array}$ & $\begin{array}{l}1 \\
1 \\
1 \\
-1 \\
1 \\
1 \\
1\end{array}$ & $\begin{array}{l}\text { b } 1,450 \\
\text { a } 1,550 \\
\text { a } 1,590 \\
\text { a } 1,672 \\
\\
1,645 \\
1,645 \\
1,645\end{array}$ & $\begin{array}{c}\mathrm{MT}_{2}+\mathrm{CT}+\mathrm{TiO}_{2} . \\
\mathrm{MT}_{2}+\mathrm{MT}+\mathrm{CT} . \\
\mathrm{MT}+\mathrm{M}_{2} \mathrm{~T}+\mathrm{CT} . \\
\mathrm{MgO}+\mathrm{M}_{2} \mathrm{~T}+\mathrm{CT} . \\
\text { d } \mathrm{MgO}+\mathrm{CT}+\mathrm{C}_{3} \mathrm{~T}_{2} . \\
\text { c } \mathrm{MgO}+\mathrm{CaO}+\mathrm{C}_{3} \mathrm{~T}_{2} . \\
\text { Do. }\end{array}$ \\
\hline
\end{tabular}

a The sample had fused at the temperature indicated.

b The sample was quen ched from the temperature indicated.

c The results indicate the possibility of a small amount of solid solution in the areas adjacent to the compoun $\mathrm{C}_{3} \mathrm{~T}_{2}$.

$\mathrm{d}$ Interpretation of powder patterns is difficult in this area due to the overlapping of some of the lines of $\mathrm{CT}$ and $\mathrm{C}_{3} \mathrm{~T}_{2}$. The results indicate that there may be a small a mount of solid solution in the areas adjacent to the compound $\mathrm{C}_{3} \mathrm{~T}_{2}$.

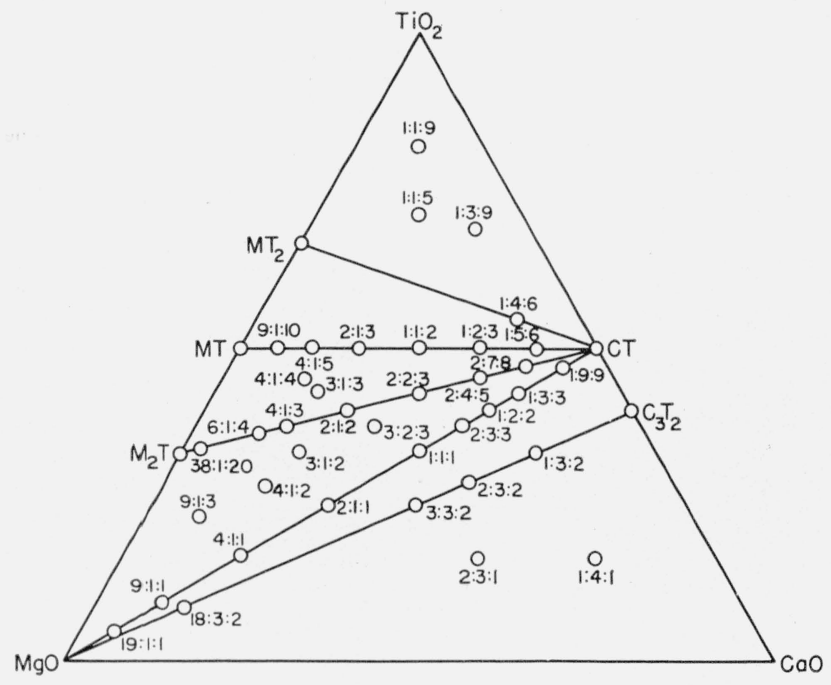

Figure 1. Compatibilityrelations inthe system $\mathrm{MgO}-\mathrm{CaO}-\mathrm{TiO}_{2}$. The compositions are indicated by numbers and placed graphically according to mole ratios.

\section{b. $\mathrm{MgO}-\mathrm{CaO}-\mathrm{SnO}_{2}$}

Sixteen compositions in this system have been prepared for study of solid-state reaction and dielectric properties. Nine of these compositions were selected for a preliminary study of compatibility relations in the system. The specimens were quenched from $1,550^{\circ} \mathrm{C}$ and analyzed by X-ray methods. The results obtained are listed in table 8 . Because the results indicated that there is little or no solidsolution development, and that there are no ternary compounds, these nine tests were sufficient to establish the binary joins existing, which are: $\mathrm{M}_{2} \mathrm{~S}-\mathrm{CS}$, $\mathrm{MgO}-\mathrm{CS}$, and $\mathrm{MgO}-\mathrm{C}_{2} \mathrm{~S}$. The arrangement of compatibility triangles is shown in figure 2 .

TABLE 8. Results of X-ray diffraction studies of specimens in the $\mathrm{MgO}-\mathrm{CaO}-\mathrm{SnO}_{2}$ system

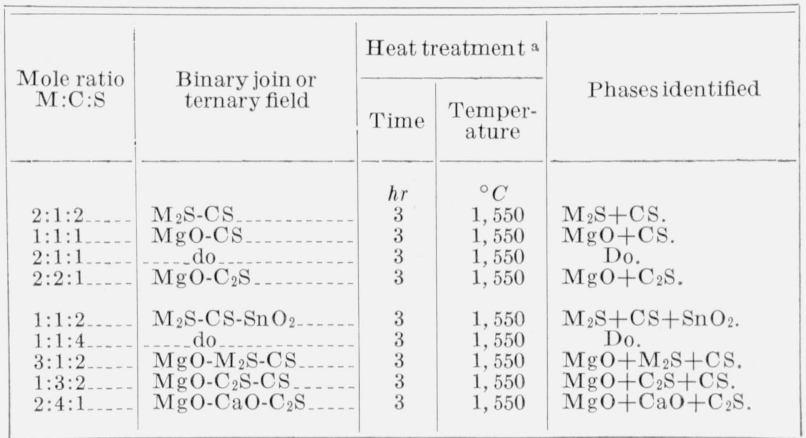

a Each sample had been previously calcined for 4 hours at $1,100^{\circ} \mathrm{C}$. Each specimen was quenched in air from the temperature indicated

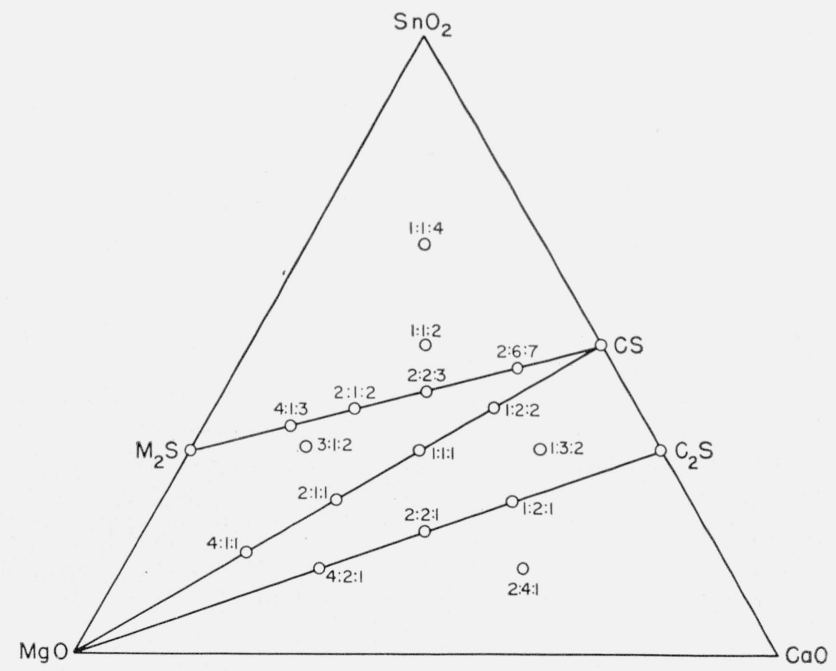

Figure 2. Compatibility relations in the system $\mathrm{MgO}-\mathrm{CaO}-\mathrm{SnO}_{2}$.

The compositions are indicated by numbers and placed graphically according to mole ratios. The compound $\mathrm{MgO} \cdot \mathrm{SnO}_{2}$ is not indicated as it decomposes between $800^{\circ}$ and $1,000^{\circ} \mathrm{C}$, and the specimens studied here were all heated to $1,550^{\circ} \mathrm{C}$. 


\section{c. $\mathrm{MgO}-\mathrm{SnO}_{2}-\mathrm{TiO}_{2}$}

Twenty compositions in the ternary field were given suitable heat treatment and, after cooling or quenching, were analyzed by X-ray and petrographic methods. From the results of these tests, which are listed in table 9, the arrangement of composition triangles was determined. An estimate of the solidsolution areas in the system was also obtained from these results.

TABLE 9. Results of X-ray diffraction study of specimens in the $\mathrm{MgO}-\mathrm{SnO}_{2}-\mathrm{TiO}_{2}$ system

\begin{tabular}{|c|c|c|c|c|}
\hline \multirow{2}{*}{$\begin{array}{c}\text { Mole ratio } \\
\text { M:S:T }\end{array}$} & \multirow{2}{*}{$\begin{array}{l}\text { Binary join or } \\
\text { ternary field }\end{array}$} & \multicolumn{2}{|c|}{ Heat treatmenta } & \multirow{2}{*}{$\begin{array}{l}\text { Phases identified } \\
\text { (ss=solid solution) }\end{array}$} \\
\hline & & Time & $\begin{array}{l}\text { Tempera- } \\
\text { ture }\end{array}$ & \\
\hline & & $h r$ & ${ }^{\circ} \mathrm{C}$ & \\
\hline & & 3 & 1,550 & $\mathrm{M}_{2} \mathrm{ST}$ (single phase). \\
\hline $\begin{array}{l}1: 1: 2 \\
1: 4: 2\end{array}$ & $\begin{array}{l}\mathrm{MT}_{2}-\mathrm{SnO}_{2} \ldots \\
\text { do }\end{array}$ & $\begin{array}{l}3 \\
3\end{array}$ & $\begin{array}{l}1,550 \\
1,550\end{array}$ & $\begin{array}{c}\mathrm{MT}_{2} \mathrm{ss}+\mathrm{SnO}_{2} \mathrm{ss} \\
\mathrm{Do}_{0}\end{array}$ \\
\hline $3: 1: 3^{\mathrm{b}}$ & $\mathrm{MT}_{2}-\mathrm{M}_{2} \mathrm{ST}$ & & & Equilibrium condi- \\
\hline & & & & $\begin{array}{l}\text { tions could not be } \\
\text { obtained. }\end{array}$ \\
\hline $3: 1: 2 \ldots$ & $\mathrm{MT}-\mathrm{M}_{2} \mathrm{ST} \ldots$ & 3 & 1,550 & $\left(\mathrm{MT}-\mathrm{M}_{2} \mathrm{ST}\right) \mathrm{ss}$ \\
\hline $5: 1: 4$ & $\ldots$ do $\ldots . . .$. & 3 & 1,550 & $\begin{array}{l}\left(\mathrm{MT}-\mathrm{M}_{2} \mathrm{ST}\right) \mathrm{ss}+\text { trace } \\
\mathrm{M}_{2} \mathrm{~S} .\end{array}$ \\
\hline $3: 1: 1$ & $\mathrm{MT}-\mathrm{M}_{2} \mathrm{~S} \ldots$ & 2.5 & 1,550 & $\mathrm{MTss}+\mathrm{M}_{2} \mathrm{~S} \mathrm{ss}$. \\
\hline & ..... do ..... & 16 & 1,300 & Do. \\
\hline & do & $\begin{array}{c}15 \\
3.5\end{array}$ & 1,400 & None equilibrium. \\
\hline 4: & $\mathrm{M}_{2} \mathrm{~T}-\mathrm{M}_{2} \mathrm{~S} \ldots$ & 3.5 & 1,550 & $\begin{array}{l}\text { MgO. } \\
\text { MgOss+trace }\end{array}$ \\
\hline $4: 2: 1$ & $\mathrm{M}_{2} \mathrm{~S}-\mathrm{M}_{2} \mathrm{ST}$ & 3 & 1,550 & $\mathrm{M}_{2} \mathrm{Sss}+\mathrm{M}_{2} \mathrm{ST} \mathrm{ss}$ \\
\hline $2: 3: 1$ & $\mathrm{M}_{2} \mathrm{ST}-\mathrm{SnO}_{2} \ldots$ & 3 & b1, 550 & $\mathrm{M}_{2} \mathrm{ST}+\mathrm{SnO}_{2} \mathrm{ss}$ \\
\hline & $\mathrm{MT}_{2}-\mathrm{SnO}_{2}-\mathrm{TiO}_{2}$ & 15 & 1,400 & $\begin{array}{l}\mathrm{MT}_{2} \mathrm{SS} \\
\mathrm{SS}\end{array}$ \\
\hline $6: 1: 6 \ldots$ & $\mathrm{MT}_{2}-\mathrm{MT}-\mathrm{M}_{2} \mathrm{ST} \ldots$ & 1 & 1,550 & $\mathrm{MT}_{2} \mathrm{SS}+\left(\mathrm{MT}-\mathrm{M}_{2} \mathrm{ST}\right)$ \\
\hline $1: 1: 1$ & $\mathrm{MT}_{2}-\mathrm{M}_{2} \mathrm{ST}-\mathrm{SnO} \mathrm{O}_{2-}$ & 2.5 & 1,550 & $\mathrm{MT}_{2} \mathrm{ss}+\mathrm{M}_{2} \mathrm{ST}+$ \\
\hline $2: 1: 2 \ldots$ & $\ldots$ do _....... & 3 & 1,550 & Do. \\
\hline $3: 2: 1$ & $\mathrm{M}_{2} \mathrm{~S}-\mathrm{M}_{2} \mathrm{ST}-\mathrm{SnO}_{2 \ldots}$ & 2.5 & 1,550 & $\mathrm{M}_{2} \mathrm{~S}$ ss $+\mathrm{M}_{2} \mathrm{ST}$ ss+ \\
\hline $8: 1: 4$ & $\mathrm{M}_{2} \mathrm{~T}-\mathrm{MT}-\mathrm{M}_{2} \mathrm{~S} \ldots$ & 2.5 & 1,550 & $\left(\mathrm{M}_{2} \mathrm{~S}-\mathrm{M}_{2} \mathrm{~T}\right) \mathrm{ss}+\mathrm{MT}$ \\
\hline $6: 2: 3$ & $\mathrm{M}_{2} \mathrm{~S}-\mathrm{MT}-\mathrm{M}_{2} \mathrm{ST}$ & 3 & 1,550 & $\mathrm{M}_{2} \mathrm{~S} \mathrm{ss}+\left(\mathrm{MT}-\mathrm{M}_{2} \mathrm{ST}\right)$ \\
\hline $6: 1: 1$ & $\mathrm{MgO}-\mathrm{M}_{2} \mathrm{~S}-\mathrm{M}_{2} \mathrm{~T} \ldots$ & 3 & b1, 550 & $\mathrm{MgO}+\left(\mathrm{M}_{2} \mathrm{~S}-\mathrm{M}_{2} \mathrm{~T}\right) \mathrm{ss}$. \\
\hline
\end{tabular}

a Each sample had been previously calcined for 4 hours at $1,100^{\circ} \mathrm{C}$.

bThe specimen was slowly cooled. All others were quenched from the temperature indicated.

The compatibility relations and the location of the compositions studied are shown in figure 3 . The estimated solid-solution limits are indicated in figure 4. Extensive solid-solution development is noted throughout the system. However, the solidsolution areas and limits shown are not considered located with a high degree of accuracy. In addition, it is highly probable that the limits would change with differing heat treatments.

There is indicated a ternary compound having the probable formula $2 \mathrm{MgO} \cdot \mathrm{SnO}_{2} \cdot \mathrm{TiO}_{2}$ or $\mathrm{M}_{2} \mathrm{ST}$. This compound is of the ilmenite type, is isostructural with the compound $\mathrm{MgO} \cdot \mathrm{TiO}_{2}$, and forms a continuous series of solid solutions with it. The fact that all compositions on the M'T- $\mathrm{M}_{2} \mathrm{ST}$ join consist of a single phase and show a regular variation in lattice

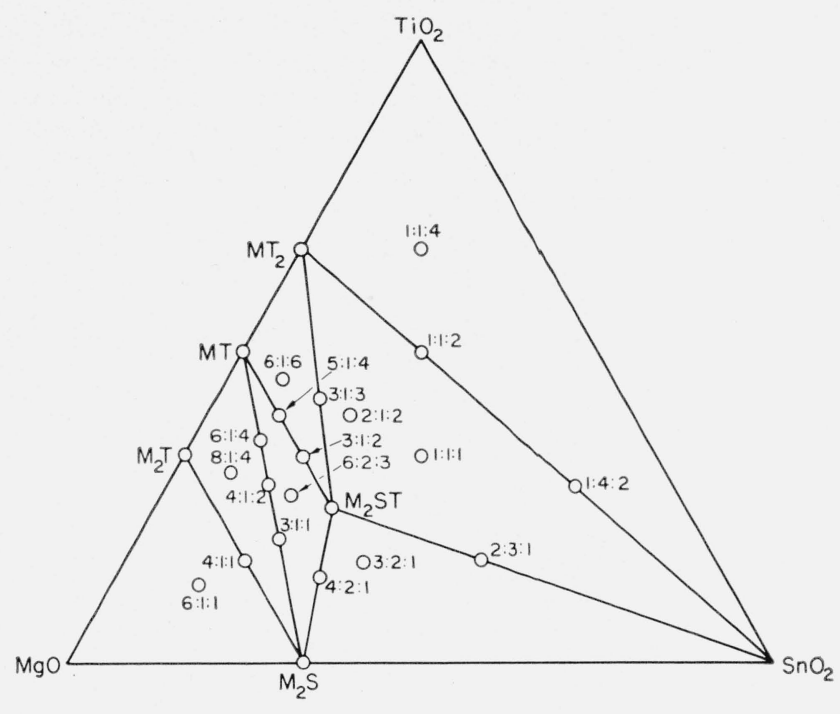

Figure 3. Compatibility relations in the system $\mathrm{MgO}-\mathrm{SnO}_{2}-\mathrm{TiO}_{2}$.

The compositions are indicated by numbers and placed graphically according to mole ratios. All specimens were heated to $1,300^{\circ} \mathrm{C}$ or higher. Since the com. pound $\mathrm{MgO} \cdot \mathrm{SnO}_{2}$ decomposes at a much lower temperature, it is not indicated
on the diagram.

parameters and indices of refraction makes it quite difficult to establish unambiguously the formula of the ternary compound. The lattice parameters of the ternary composition $\mathrm{M}_{2} \mathrm{ST}$ are $a=5.533 \mathrm{~A}$, $\alpha=55.6^{\circ}$. An indexed powder pattern for this composition is included as table 10. The optical properties of this composition are: uniaxial negative, $\epsilon=1.85, \omega=2.07$.

TABLE 10. X-ray diffraction pattern of the compound $2 \mathrm{MgO} . \mathrm{SnO}_{2}$. $\mathrm{TiO}_{2}$

\begin{tabular}{|c|c|c|c|c|c|c|c|}
\hline$h k l$ & $\begin{array}{l}1 / d^{2} \\
\text { obs. }\end{array}$ & $\begin{array}{c}1 / d^{2} \\
\text { calc. }\end{array}$ & R. I. a & $h k l$ & $\begin{array}{l}1 / d^{2} \\
\text { obs. }\end{array}$ & $\begin{array}{c}1 / d^{2} \\
\text { calc. }\end{array}$ & R. I. a \\
\hline 111 & 0.046 & 0.046 & 90 & $12 \overline{2}$ & .657 & .655 & 3 \\
\hline 010 & .055 & .055 & 75 & 341 & 677 & .677 & 4 \\
\hline 110 & .071 & .071 & 41 & 442 & .7103 & .7115 & 7 \\
\hline 121 & .132 & .132 & $100+$ & 231 & .7329 & .7322 & 4 \\
\hline 011 & .151 & .150 & $100++$ & 240 & .7848 & .7845 & 5 \\
\hline 222 & .184 & .184 & 8 & 352 & .8605 & .8616 & 8 \\
\hline 120 & .196 & .196 & 62 & 251 & .9679 & .9777 & 5 \\
\hline 111 & .206 & .205 & 6 & $14 \overline{1}$ & 1.0338 & 1.0324 & 6 \\
\hline 220 & .282 & .282 & 29 & 151 & 1. 0519 & 1.0510 & 9 \\
\hline 232 & .300 & .300 & 17 & $04 \overline{1}$ & 1. 0983 & 1.0966 & 4 \\
\hline 231 & .334 & .334 & 73 & 440 & 1.1283 & 1. 1278 & 6 \\
\hline 021 & .356 & .355 & 4 & 451 & 1.1609 & 1.1618 & 6 \\
\hline $12 \overline{1}$ & .376 & .371 & 8 & 250 & 1. 1991 & 1. 2011 & 13 \\
\hline 124 & .432 & .432 & 31 & 150 & 1. 2358 & 1. 2347 & 15 \\
\hline 121 & .451 & .450 & 60 & $03 \overline{3}$ & 1. 3497 & 1. 3508 & 19 \\
\hline 030 & .497 & .496 & 7 & $14 \overline{2}$ & 1. 3994 & 1. 3968 & 7 \\
\hline 242 & .526 & .527 & 4 & 361 & 1.4631 & 1.4620 & 7 \\
\hline 343 & .559 & .561 & 18 & $24 \overline{2}$ & 1. 4851 & 1.4826 & 3 \\
\hline $02 \overline{2}$ & .600 & .600 & 13 & 664 & 1. 5132 & 1.5093 & 6 \\
\hline 141 & .636 & .634 & 3 & & & & \\
\hline
\end{tabular}

a R. I. is the intensity of diffraction peaks relative to the strongest peak. 


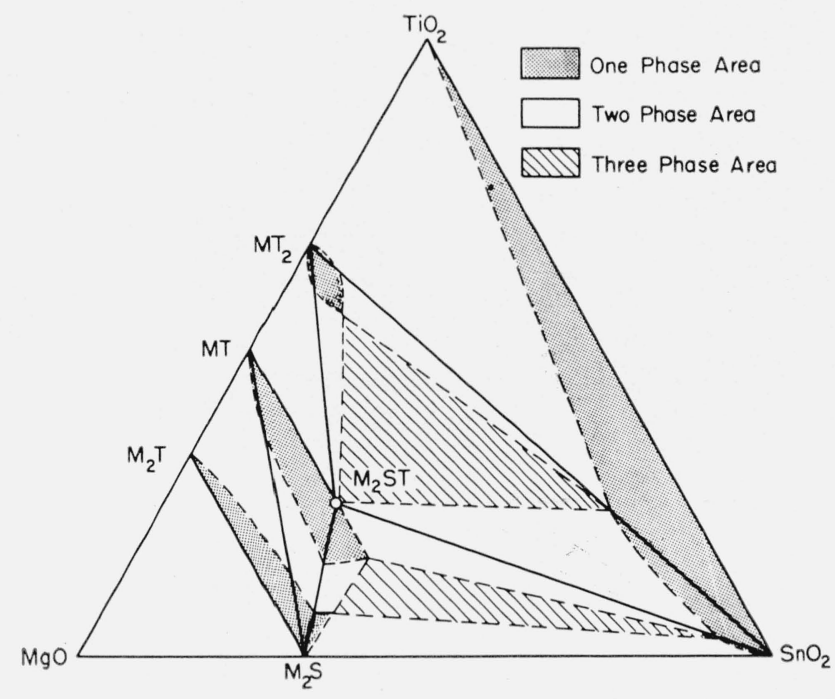

FIgURE 4. Estimated solid-solution areas in the system $\mathrm{MgO}-\mathrm{SnO}_{2}-\mathrm{TiO}_{2}$.

The temperature range involved is between $1,300^{\circ}$ and $1,550^{\circ} \mathrm{C}$.

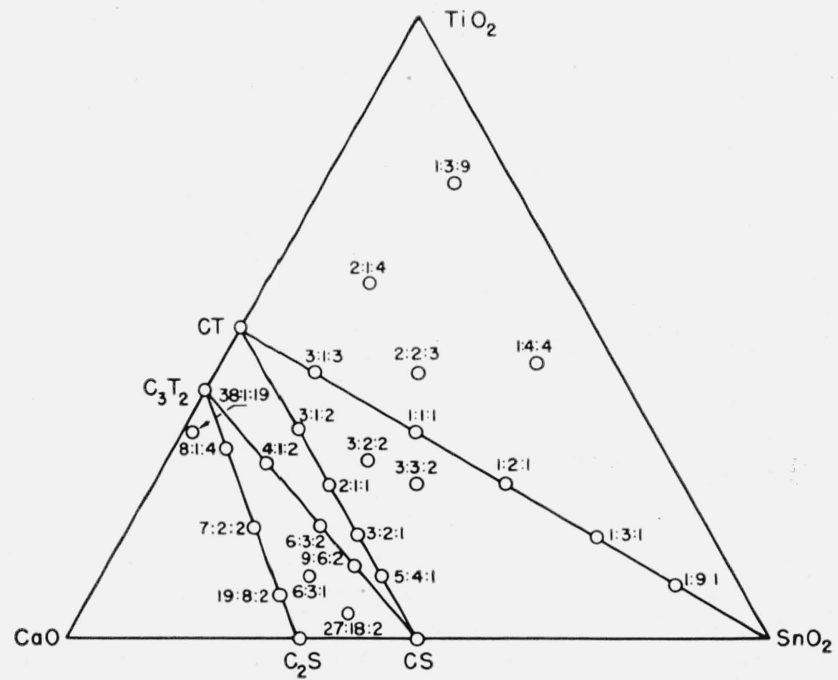

Figure 5. Compatibility relations in the system $\mathrm{CaO}-\mathrm{SnO}_{2}-\mathrm{TiO}_{2}$

The compositions are indicated by numbers and placed graphically according to mole ratios.

\section{d. $\mathrm{CaO}-\mathrm{SnO}_{2}-\mathrm{TiO}_{2}$}

In this system, 22 selected ternary compositions were examined by X-ray methods after having been quenched from a temperature of $1,300^{\circ}$ to $1,550^{\circ} \mathrm{C}$. Figure 5, showing the compatibility relations, was constructed from data in table 11. The binary joins are CT-SnO, CT-CS, $\mathrm{C}_{3} \mathrm{~T}_{2}-\mathrm{CS}$, and $\mathrm{C}_{3} \mathrm{~T}_{2}-\mathrm{C}_{2} \mathrm{~S}$. Solid solutions were noted in all parts of the system. The estimated limits of the solid-solution areas are shown in figure 6.

In this case, as in that of the $\mathrm{MgO}-\mathrm{SnO}_{2}-\mathrm{TiO}_{2}$ system, it is considered that the solid-solution limits are only approximate and that they would shift with heat treatments other than those used in this study.

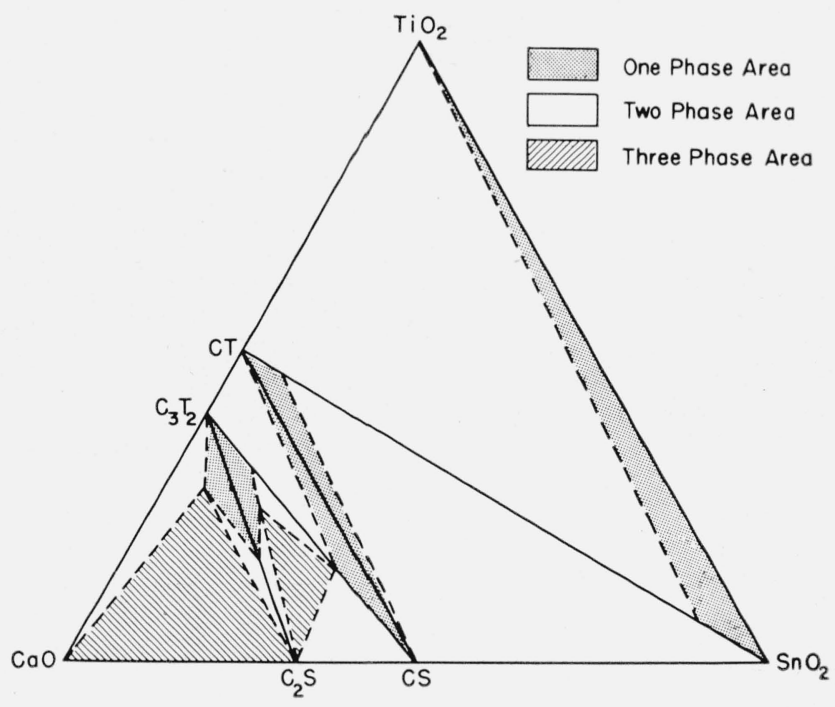

Figure 6. Estimated solid-solution areas in the system $\mathrm{CaO}-\mathrm{SnO}_{2}-\mathrm{TiO}_{2}$.

The temperature range involved is between $1,300^{\circ}$ and $1,550^{\circ} \mathrm{C}$.

TABLE 11. Results of X-ray study of selected compositions in the system $\mathrm{CaO}-\mathrm{SnO}_{2}-\mathrm{TiO}_{2}$

\begin{tabular}{|c|c|c|c|c|}
\hline \multirow{2}{*}{$\begin{array}{l}\text { Mole ratio } \\
\text { C:S:T }\end{array}$} & \multirow{2}{*}{$\begin{array}{l}\text { Binary join or } \\
\text { ternary field }\end{array}$} & \multicolumn{2}{|c|}{ Heat treatmenta } & \multirow{2}{*}{$\begin{array}{l}\text { Phases identified } \\
\text { (ss = solid solution) }\end{array}$} \\
\hline & & Time & $\begin{array}{l}\text { Temper- } \\
\text { ature }\end{array}$ & \\
\hline $\begin{array}{l}3: 1: 3 \ldots \ldots \\
1: 1: 1 \ldots \\
1: 3: 1 \ldots \\
1: 9: 1 \ldots \\
3: 1: 2 \ldots \\
3: 2: 1 \ldots \\
\end{array}$ & $\begin{array}{l}\mathrm{CT}-\mathrm{SnO}_{2} \ldots \\
\mathrm{do} \\
\mathrm{CT}-\mathrm{CS} \\
\end{array}$ & $\begin{array}{l}h r \\
2.5 \\
3 \\
2.5 \\
3 \\
3 \\
3\end{array}$ & $\begin{array}{c}{ }^{\circ} C \\
1,550 \\
1,550 \\
1,550 \\
1,550 \\
1,550 \\
1,550\end{array}$ & $\begin{array}{l}\mathrm{CT} \text { ss+ } \mathrm{SnO}_{2} \mathrm{ss} . \\
\text { Do. } \\
\text { Do. } \\
\text { Do. } \\
\text { (CT-CS) ss. } \\
\text { Do. }\end{array}$ \\
\hline $4: 1: 2 \ldots$ & $\mathrm{C}_{3} \mathrm{~T}_{2}-\mathrm{CS} \ldots$ & 3 & 1,550 & $\begin{array}{l}\text { CS ss+small amount } \\
\mathrm{C}_{3} \mathrm{~T}_{2} \text { ss. }\end{array}$ \\
\hline $\begin{array}{l}6: 3: 2 \\
9: 6: 2 \\
8: 1: 4 \ldots \\
7: 2: 2 \ldots \\
19: 8: 2 \ldots\end{array}$ & $\begin{array}{l}\mathrm{d} \mathrm{d}_{2} \ldots \ldots \ldots \\
\mathrm{C}_{3} \mathrm{~T}_{2}-\mathrm{C}_{2} \mathrm{~S} \\
\ldots \mathrm{do}\end{array}$ & $\begin{array}{l}3 \\
3 \\
3 \\
3 \\
3\end{array}$ & $\begin{array}{l}1,550 \\
1,550 \\
1,550 \\
1,550 \\
1,550\end{array}$ & $\begin{array}{l}\mathrm{CS} \text { ss+trace } \mathrm{C}_{3} \mathrm{~T}_{2} \mathrm{ss} . \\
\mathrm{CS} \text { ss. } \\
\mathrm{C}_{3} \mathrm{~T}_{2} \mathrm{ss} \text {. } \\
\text { Do. } \\
\mathrm{C}_{3} \mathrm{~T}_{2} \mathrm{ss}+\mathrm{C}_{2} \mathrm{~S} .\end{array}$ \\
\hline $1: 1: 4 \ldots$ & $\mathrm{CT}-\mathrm{TiO}_{2}-\mathrm{SnO}_{2} \ldots$ & 16 & 1,315 & $\underset{\mathrm{SS}}{\mathrm{CT}} \mathrm{SS}+\left(\mathrm{TiO}_{2}-\mathrm{SnO}_{2}\right)$ \\
\hline $1: 3: 9 \ldots$ & $\ldots$ do _........... & 3 & 1,400 & Do. \\
\hline $\begin{array}{l}3: 2: 2 \ldots \\
4: 4: 1\end{array}$ & $\begin{array}{c}\mathrm{CT}-\mathrm{CS}-\mathrm{SnO} \\
2 \ldots\end{array}$ & $\begin{array}{l}3 \\
3\end{array}$ & $\begin{array}{l}1,550 \\
1,550\end{array}$ & $\begin{array}{l}(\mathrm{CT}-\mathrm{CS}) \mathrm{sS}+\mathrm{SnO}_{2} \mathrm{Ss} . \\
\text { Do. }\end{array}$ \\
\hline $\begin{array}{l}7: 2: 4 \\
3: 1: 1 \\
9: 6: 1 \\
27: 18: 2 \ldots \\
4: 1: 1 \\
38: 1: 19 \\
8\end{array}$ & $\begin{array}{l}\mathrm{C}_{3} \mathrm{~T}_{2}-\mathrm{CT}-\mathrm{CS}_{2} \\
\mathrm{C}_{3} \mathrm{~T}_{2}-\mathrm{CS}-\mathrm{C}_{2} \mathrm{~S} \\
\mathrm{C}_{3} \mathrm{~T}_{2}-\mathrm{C}_{2} \mathrm{~S}-\mathrm{CaO}\end{array}$ & $\begin{array}{l}3 \\
3 \\
3 \\
3 \\
3 \\
3\end{array}$ & $\begin{array}{l}1,550 \\
1,550 \\
1,550 \\
1,550 \\
1,550 \\
1,550\end{array}$ & $\begin{array}{l}\mathrm{C}_{3} \mathrm{~T}_{2} \mathrm{SS}+(\mathrm{CT}-\mathrm{CS}) \mathrm{ss} . \\
\mathrm{CSS} \mathrm{SS}+\mathrm{C}_{2} \mathrm{~S}+\mathrm{C}_{3} \mathrm{~T}_{2} \mathrm{ss} . \\
\mathrm{CS} \mathrm{sS}+\mathrm{C}_{2} \mathrm{~S} . \\
\quad \mathrm{Do} \\
\mathrm{CaO}+\dot{\mathrm{C}}_{2} \mathrm{~S}+\mathrm{C}_{3} \mathrm{~T}_{2} \mathrm{ss} . \\
\mathrm{CaO}+\mathrm{C}_{3} \mathrm{~T}_{2} \mathrm{Ss}\end{array}$ \\
\hline
\end{tabular}

a Each sample had been previously calcined for 4 hours at $1,000^{\circ}$ to $1,100^{\circ} \mathrm{C}$ Each specimen was quenched from the temperature indicated.

\subsection{The System $\mathrm{MgO}-\mathrm{CaO}-\mathrm{SnO}_{2}-\mathrm{TiO}_{2}$}

In addition to the 19 binary joins established in the four subsidiary ternary systems, there are 13 possible binary joins across the interior of the quaternary tetrahedron. Investigation of 10 selected quaternary compositions (with the preliminary assumption that there are no quaternary compounds present) indicated that only 2 of these binary joins 


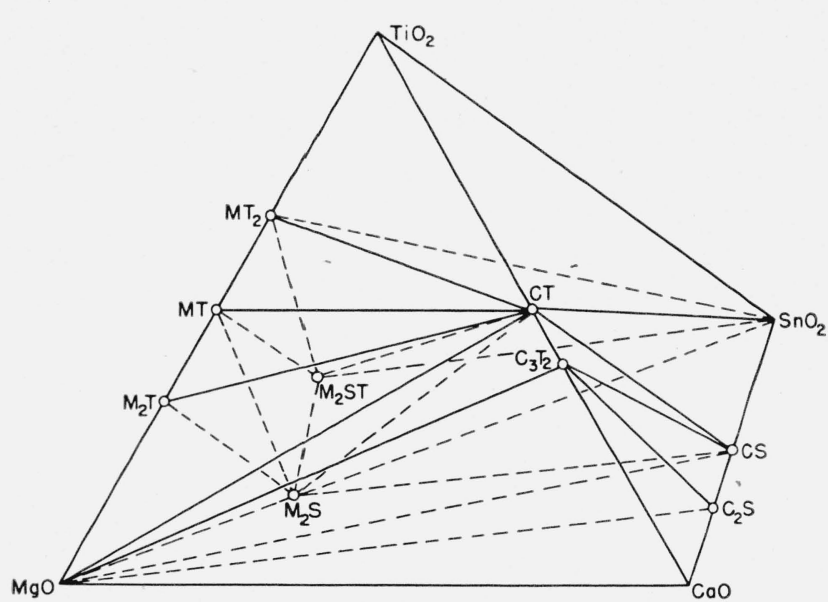

Figure 7. Compatibility relations in the system $\mathrm{MgO}-\mathrm{CaO}-\mathrm{SnO}_{2}-\mathrm{TiO}_{2}$.

No attempt has been made to indicate the extensive solid-solution development that occurs in this system.

are valid. They are the $\mathrm{M}_{2} \mathrm{~S}-\mathrm{CT}$ and $\mathrm{M}_{2} \mathrm{ST}-\mathrm{CT}$ joins. The quaternary system could then be divided into 12 subsystems or tetrahedra. In order to verify the initial assumption as to the lack of quaternary

TABLE 12. Results of X-ray diffraction studies of specimens in the $\mathrm{MgO}-\mathrm{CaO}-\mathrm{SnO}_{2}-\mathrm{TiO}_{2}$ system

\begin{tabular}{|c|c|c|c|c|}
\hline \multirow{2}{*}{$\begin{array}{l}\text { Mole ratio } \\
\mathrm{M}: \mathrm{C}: \mathrm{S}: \mathrm{T}\end{array}$} & \multirow{2}{*}{$\begin{array}{c}\text { Binary join, join } \\
\text { plane, or quaternary } \\
\text { volume }\end{array}$} & \multicolumn{2}{|c|}{ Heat treatmenta } & \multirow{2}{*}{$\begin{array}{l}\text { Phases identified } \\
\text { ( } \mathrm{ss}=\text { solid solution) }\end{array}$} \\
\hline & & Time & $\begin{array}{l}\text { Temper- } \\
\text { ature }\end{array}$ & \\
\hline $\begin{array}{l}2: 1: 1: 1 \\
2: 3: 1: 3 \ldots \\
2: 2: 1: 2 \ldots \\
2: 1: 1: 2 \ldots\end{array}$ & $\begin{array}{c}\mathrm{M}_{2} \mathrm{~S}-\mathrm{CT} \\
\mathrm{M} \mathrm{M}_{2} \mathrm{ST}-\mathrm{CT} \\
\mathrm{do}\end{array}$ & $\begin{array}{c}h r \\
3 \\
3 \\
3 \\
3\end{array}$ & $\begin{array}{l}{ }^{\circ} \mathrm{C} \\
1,550 \\
1,550 \\
1,550 \\
1,550\end{array}$ & $\begin{array}{l}\mathrm{M}_{2} \mathrm{~S} \text { ss+CT ss. } \\
\text { Do. } \\
\text { Do. } \\
\mathrm{M}_{2} \mathrm{ST} \text { ss+CT. }\end{array}$ \\
\hline $\begin{array}{l}3: 4: 3: 1 \ldots \\
2: 4: 4: 1 \\
2: 2: 2: 1 \\
3: 1: 1: 2 \\
1: 2: 1: 2\end{array}$ & $\begin{array}{l}\mathrm{MgO}-\mathrm{CT}-\mathrm{CS} \\
\mathrm{M}_{2} \mathrm{~S}-\mathrm{CT}-\mathrm{CS} \\
\mathrm{do} \\
\mathrm{M}_{2} \mathrm{~S}-\mathrm{MT}-\mathrm{CT} \\
\mathrm{M}_{2} \mathrm{~S}-\mathrm{CT}-\mathrm{SnO} \mathrm{O}_{2}\end{array}$ & $\begin{array}{l}6 \\
3 \\
3 \\
3 \\
3\end{array}$ & $\begin{array}{l}1,550 \\
1,550 \\
1,550 \\
1,400 \\
1,450\end{array}$ & $\begin{array}{l}\mathrm{MgO}+(\mathrm{CT}-\mathrm{CS}) \mathrm{ss} . \\
\mathrm{M}_{2} \mathrm{~S} \mathrm{ss}+(\mathrm{CT}-\mathrm{CS}) \mathrm{ss} . \\
\text { Do. } \\
\mathrm{M}_{2} \mathrm{~S} \text { ss+MT Ss+CT. } \\
\mathrm{M}_{2} \mathrm{~S} \text { ss+CT } \mathrm{Ss}+\mathrm{SnO}_{2}\end{array}$ \\
\hline $2: 1: 2: 1 \ldots$ & ..... do & 3 & 1,400 & Ss. \\
\hline $1: 6: 1: 2 \ldots$ & $\underset{\mathrm{C}_{3} \mathrm{~T}_{2} .}{\mathrm{Mg}-\mathrm{CaO}-\mathrm{C}_{2} \mathrm{~S}-}$ & 3 & 1,550 & $\mathrm{C}_{3} \mathrm{~T}_{2} \mathrm{Ss}+\mathrm{CaO}+\mathrm{MgO}$. \\
\hline $\begin{array}{l}1: 1: 2: 4 \\
1: 15: 4: 4 \ldots\end{array}$ & $\begin{array}{l}\mathrm{M}_{2} \mathrm{~S}-\mathrm{M}_{2} \mathrm{~T}-\mathrm{MT}-\mathrm{CT} \\
\mathrm{do}\end{array}$ & $\begin{array}{l}3 \\
3\end{array}$ & $\begin{array}{l}1,400 \\
1,400\end{array}$ & $\begin{array}{l}\mathrm{C}_{3} \mathrm{~T}_{2} \mathrm{Ss}+\mathrm{CaO} \\
\text { Do. }\end{array}$ \\
\hline $\begin{array}{l}1: 6: 2: 2 \\
5: 1: 1: 2 \ldots\end{array}$ & $\begin{array}{l}\mathrm{MgO}-\mathrm{C}_{2} \mathrm{~S}-\mathrm{CS}-\mathrm{C}_{3} \mathrm{~T}_{2} \\
\mathrm{MgO}-\mathrm{M}_{2} \mathrm{~S}-\mathrm{M}_{2} \mathrm{~T}- \\
\mathrm{CT} .\end{array}$ & $\begin{array}{l}3 \\
3\end{array}$ & $\begin{array}{l}1,550 \\
1,550\end{array}$ & $\begin{array}{l}\mathrm{C}_{3} \mathrm{~T}_{2} \mathrm{Ss}+\mathrm{CS} \mathrm{ss}+\mathrm{MgO} \\
\left(\mathrm{M}_{2} \mathrm{~T}-\mathrm{M}_{2} \mathrm{~S}\right) \mathrm{ss}+\mathrm{CT}+ \\
\mathrm{MgO} .\end{array}$ \\
\hline $1: 5: 1: 3 \ldots$ & $\mathrm{MgO}-\mathrm{CS}-\mathrm{CT}-\mathrm{C}_{3} \mathrm{~T}_{2}$ & 3 & 1,550 & $\mathrm{C}_{3} \mathrm{~T}_{2} \mathrm{SS}+(\mathrm{CT}-\mathrm{CS})$ \\
\hline $6: 2: 2: 1 \ldots$ & $\mathrm{MgO}-\mathrm{M}_{2} \mathrm{~S}-\mathrm{CS}-\mathrm{CT}$ & 3 & 1,550 & $\mathrm{MgO}+\mathrm{M}_{2} \mathrm{~S}+(\mathrm{CT}-$ \\
\hline $5: 1: 1: 3 \ldots$ & $\mathrm{M}_{2} \mathrm{~S}-\mathrm{M}_{2} \mathrm{~T}-\mathrm{MT}-\mathrm{CT}$. & 3 & 1,400 & $\left(\mathrm{M}_{2} \mathrm{~S}-\mathrm{M}_{2} \mathrm{~T}\right) \mathrm{ss}+\mathrm{MT}$ \\
\hline $5: 1: 2: 3 \ldots$ & $\begin{array}{l}\mathrm{M}_{2} \mathrm{~S}-\mathrm{M}_{2} \mathrm{~S} \mathrm{~T}-\mathrm{MT} \\
\mathrm{CT} .\end{array}$ & 3 & 1,400 & $\begin{array}{l}\mathrm{M}_{2} \mathrm{~S} S \mathrm{SS}+\left(\mathrm{M}_{2} \mathrm{ST}-\mathrm{MT}\right) \\
\mathrm{SS}+\mathrm{CT} .\end{array}$ \\
\hline $4: 1: 3: 2 \ldots$ & $\begin{array}{c}\mathrm{M}_{2} \mathrm{~S}-\mathrm{M}_{2} \mathrm{ST}-\mathrm{CT}- \\
\mathrm{SnO}_{2} .\end{array}$ & 3 & 1,450 & $\begin{array}{c}\mathrm{M}_{2} \mathrm{~S} \mathrm{SS}+\mathrm{M}_{2} \mathrm{ST}+\mathrm{CT} \\
\mathrm{SS}+\mathrm{SnO} \mathrm{O}_{2} .\end{array}$ \\
\hline $2: 2: 3: 1 \ldots$ & $\mathrm{M}_{2} \mathrm{~S}-\mathrm{CS}-\mathrm{CT}-\mathrm{SnO}_{2--}$ & 3 & 1,550 & $\begin{array}{l}\mathrm{M}_{2} \mathrm{Sss}+(\mathrm{CT}-\mathrm{CS}) \\
\mathrm{Ss}+\mathrm{SnO}_{2}\end{array}$ \\
\hline $1: 1: 1: 2 \ldots$ & $\begin{array}{l}\mathrm{M}_{2} \mathrm{ST}-\mathrm{MT}_{2}-\mathrm{CT}- \\
\mathrm{SnO}_{2} .\end{array}$ & 3 & 1,550 & $\begin{array}{c}\mathrm{MT}_{2} \mathrm{ss}+\mathrm{M}_{2} \mathrm{ST} \\
\mathrm{CT}+\mathrm{SnO}_{2} \mathrm{ss}\end{array}$ \\
\hline $4: 1: 1: 5 \ldots$ & $\begin{array}{l}\mathrm{M}_{2} \mathrm{ST}-\mathrm{MT}-\mathrm{M} \mathrm{T}_{2}- \\
\mathrm{CT} \text {. }\end{array}$ & 5 & 1,400 & $\begin{array}{l}\left(\mathrm{M}_{2} \mathrm{ST}-\mathrm{MT}\right) \mathrm{sS}+ \\
\mathrm{MT}_{2} \mathrm{SS}+\mathrm{CT}\end{array}$ \\
\hline $1: 1: 1: 4 \ldots$ & $\begin{array}{l}\mathrm{M} \mathrm{T}_{2}-\mathrm{C} \mathrm{T}-\mathrm{TiO}_{2}- \\
\mathrm{SnO}_{2} \text {. }\end{array}$ & 4 & 1,350 & $\begin{array}{l}\mathrm{MT}_{2}+\mathrm{CT}^{\mathrm{T}}+\mathrm{TiO}_{2} \\
\mathrm{Ss}+\mathrm{SnO}_{2} \mathrm{ss} .\end{array}$ \\
\hline
\end{tabular}

a Each sample had been previously ealcined for 4 hours at $1,000^{\circ}$ to $1,100^{\circ} \mathrm{C}$ Each specimen was quenched from the temperature indicated.

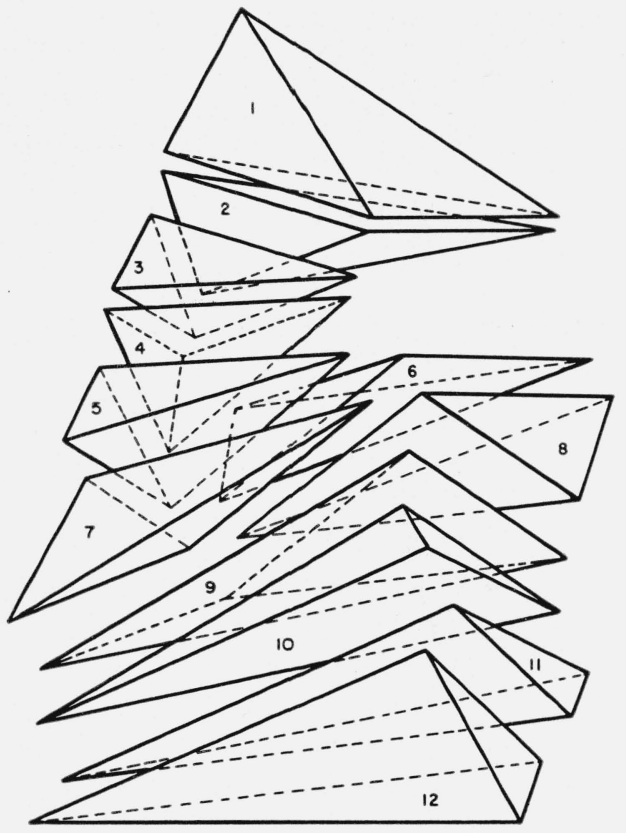

FiguRe 8. An "expanded" version of figure \%.

\begin{tabular}{|c|c|}
\hline No. & $\begin{array}{l}\text { End members of the } 12 \text { subtetrahedra of the system } \\
\qquad \mathrm{MgO}-\mathrm{CaO}-\mathrm{SnO}_{2}-\mathrm{TiO}_{2}\end{array}$ \\
\hline $\begin{array}{ll}1 \\
2 \\
3 \\
4 \\
5 \\
-\end{array}$ & $\begin{array}{l}\mathrm{MT}_{2} \text {-CT-TiO }-\mathrm{TiO}_{2}-\mathrm{SnO}_{2} \\
\mathrm{MT}_{2} \text { - } \mathrm{M}_{2} \mathrm{ST}-\mathrm{CT}-\mathrm{SnO} \mathrm{O}_{2} \\
\mathrm{MT}_{2}-\mathrm{MT}-\mathrm{M}_{2} \mathrm{ST}-\mathrm{CT} \text {. } \\
\text { MT-M } \mathrm{M}_{2} \mathrm{~S}-\mathrm{M}_{2} \mathrm{ST}-\mathrm{CT} \text {. } \\
\text { MT- } \mathrm{M}_{2} \mathrm{~T}-\mathrm{M}_{2} \mathrm{~S}-\mathrm{CT} .\end{array}$ \\
\hline $\begin{array}{l}6 \ldots \ldots \\
7 \\
8 \\
9 \\
10 \ldots \ldots\end{array}$ & $\begin{array}{l}\mathrm{M}_{2} \mathrm{~S}-\mathrm{M}_{2} \mathrm{ST}-\mathrm{CT}-\mathrm{SnO}_{2} . \\
\mathrm{MgO}_{2} \mathrm{M}-\mathrm{M}_{2} \mathrm{~S}-\mathrm{CT} . \\
\mathrm{M}_{2} \mathrm{~S}-\mathrm{CT}-\mathrm{CS}-\mathrm{SnO}_{2} . \\
\mathrm{MgO}_{2} \mathrm{M}_{2} \mathrm{~S}-\mathrm{CS}-\mathrm{CT} \text {. } \\
\mathrm{MgO}-\mathrm{CS}-\mathrm{CT}-\mathrm{C}_{3} \mathrm{~T}_{2} .\end{array}$ \\
\hline $11 \ldots$ & $\begin{array}{l}\mathrm{MgO}-\mathrm{C}_{2} \mathrm{~S}-\mathrm{CS}-\mathrm{C}_{3} \mathrm{~T}_{2} \\
\mathrm{MgO}-\mathrm{CaO}-\mathrm{C}_{2} \mathrm{~S}-\mathrm{C}_{3} \mathrm{~T}_{2}\end{array}$ \\
\hline
\end{tabular}

compounds, at least one composition in the interior of each of the subtetrahedra was studied. In each case the expected phases were identified, and no indication of the presence of any quaternary compound was obtained. Solid-solution development was observed in all of the quaternary compositions. The results of the tests on quaternary samples are given in table 12. The arrangement of composition tetrahedra is illustrated in figures 7 and 8 , in which no attempt has been made to indicate solid solutions.

\section{Results of Dielectric Testing}

\subsection{The System $\mathrm{MgO}-\mathrm{CaO}-\mathrm{TiO}_{2}$}

The circles in figure 1 represent compositions which were formed into appropriate specimens and tested for their dielectric properties. The results of these tests are listed in tables 13, 14, and 15 . The maturing temperatures were found to be high, 
TABLE 13. Results of dielectric testing

\begin{tabular}{|c|c|c|c|c|c|c|c|c|c|c|c|}
\hline \multirow{2}{*}{ Mole ratio } & \multirow{2}{*}{ Binary join, ternary field, or quaternary volume } & \multicolumn{2}{|c|}{ Heat treatment a } & \multirow{2}{*}{$\underset{\text { age }}{\text { Shrink- }}$} & \multirow{2}{*}{$\begin{array}{l}\text { Absorp- } \\
\text { tion }\end{array}$} & \multicolumn{3}{|c|}{$\begin{array}{l}\text { Dielectric constant, } K, \\
\text { at } 25^{\circ} \mathrm{C} \text { and - }\end{array}$} & \multicolumn{3}{|c|}{$\begin{array}{l}\text { Reciprocal, } Q \text {, of power factor } \\
\text { at } 25^{\circ} \mathrm{C} \text { and - }\end{array}$} \\
\hline & & Time & $\begin{array}{c}\text { Temper- } \\
\text { ature }\end{array}$ & & & $50 \mathrm{kc}$ & $1 \mathrm{Me}$ & $20 \mathrm{Me}$ & $50 \mathrm{kc}$ & $1 \mathrm{Me}$ & $20 \mathrm{Mc}$ \\
\hline \multicolumn{12}{|c|}{ The system $\mathrm{MgO}-\mathrm{CaO}-\mathrm{TiO}_{2}$} \\
\hline $\begin{array}{l}4: 1: 5 \ldots \ldots . \\
2: 1: 3 \ldots \ldots \\
1: 1: 2 \\
1: 2: 3 \\
1: 5: 6 \ldots \ldots\end{array}$ & $\begin{array}{l}\text { MT-CT } \ldots \text { do } \\
\text { do }\end{array}$ & $\begin{array}{l}h r \\
1 \\
1 \\
1 \\
2 \\
1\end{array}$ & $\begin{array}{l}{ }^{\circ} \mathrm{C} \\
1,500 \\
1,500 \\
1,500 \\
1,500 \\
1,500\end{array}$ & $\begin{array}{r}\% \\
14.5 \\
11.4 \\
14.0 \\
12.6 \\
16.6\end{array}$ & $\begin{array}{r}\% \\
0.00 \\
.13 \\
.06 \\
.06 \\
.02\end{array}$ & $\begin{array}{l}35.1 \\
54.1 \\
78.6 \\
110 \\
144\end{array}$ & $\begin{array}{l}35.1 \\
54.1 \\
78.5 \\
100 \\
143\end{array}$ & $\begin{array}{l}35.0 \\
54.1 \\
78.1 \\
108 \\
145\end{array}$ & $\begin{array}{r}1,100 \\
900 \\
10,000 \\
3,000 \\
10,000\end{array}$ & $\begin{array}{r}3,000 \\
9,000 \\
10,000 \\
9.000 \\
10,000\end{array}$ & $\begin{array}{l}3,000 \\
1,400 \\
700 \\
6.000 \\
3,000\end{array}$ \\
\hline $\begin{array}{l}38: 1: 20 \\
6: 1: 4 \ldots \\
4: 1: 3 \\
2: 1: 2 \\
2: 2: 3 \\
2: 4: 5 \\
2: 7: 8 \\
2\end{array}$ & $\begin{array}{l}\mathrm{M}_{2} \mathrm{~T}-\mathrm{CT} \\
\text { do } \\
\text { do } \\
\text { do }\end{array}$ & $\begin{array}{l}1 \\
2 \\
1 \\
1 \\
1 \\
1 \\
1\end{array}$ & $\begin{array}{l}1,550 \\
1,550 \\
1,540 \\
1,550 \\
1,550 \\
1,550 \\
1,550\end{array}$ & $\begin{array}{l}14.3 \\
16.0 \\
13.8 \\
11.8 \\
12.7 \\
16.0 \\
17.9\end{array}$ & $\begin{array}{l}.02 \\
.01 \\
.19 \\
.00 \\
.05 \\
.00 \\
.17\end{array}$ & $\begin{array}{l}18.0 \\
31.6 \\
38.0 \\
60.6 \\
92.9 \\
122 \\
135\end{array}$ & $\begin{array}{l}17.8 \\
31.6 \\
38.0 \\
60.6 \\
92.7 \\
121 \\
135\end{array}$ & $\begin{array}{l}17.3 \\
31.6 \\
37.6 \\
60.6 \\
92.7 \\
122 \\
135\end{array}$ & $\begin{array}{r}4,000 \\
10,000 \\
1,100 \\
10,000 \\
9,000 \\
4,000 \\
6,000\end{array}$ & $\begin{array}{r}2,000 \\
10,000 \\
6,000 \\
10,000 \\
7,000 \\
10,000 \\
9,000\end{array}$ & $\begin{array}{r}8,000 \\
2,000 \\
1,300 \\
2,000 \\
700 \\
7,000 \\
10,000\end{array}$ \\
\hline 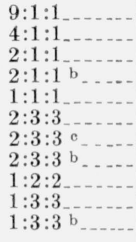 & \begin{tabular}{l}
$\mathrm{MgO}-\mathrm{CT}$ \\
\hdashline do \\
do \\
do \\
do
\end{tabular} & $\begin{array}{l}1 \\
1 \\
1 \\
1 \\
1 \\
1^{1 / 2} \\
1 \\
1^{1 / 2} \\
1^{1 / 2}\end{array}$ & $\begin{array}{l}1,725 \\
1,725 \\
1,725 \\
1,500 \\
1,725 \\
1,730 \\
1,500 \\
1,500 \\
1,725 \\
1,730 \\
1,500\end{array}$ & $\begin{array}{l}15.1 \\
14.7 \\
15.4 \\
13.5 \\
14.0 \\
14.0 \\
12.2 \\
13.2 \\
14.7 \\
14.4 \\
13.4\end{array}$ & $\begin{array}{l}.13 \\
.07 \\
.07 \\
.00 \\
.04 \\
.00 \\
.00 \\
.00 \\
.02 \\
.00\end{array}$ & $\begin{array}{l}23.6 \\
43 \\
73 \\
69 \\
98 \\
119 \\
106 \\
109 \\
153 \\
129\end{array}$ & $\begin{array}{l}23.6 \\
43 \\
73 \\
69 \\
98 \\
118 \\
106 \\
109 \\
128 \\
153 \\
129\end{array}$ & $\begin{array}{l}23.6 \\
43 \\
73 \\
69 \\
98 \\
118 \\
106 \\
109 \\
126 \\
152 \\
129\end{array}$ & $\begin{array}{l}3,000 \\
3,000 \\
2,500 \\
3,000 \\
4,000 \\
4,000 \\
1,000 \\
1,000 \\
-2,400 \\
1,000\end{array}$ & $\begin{array}{r}10,000 \\
10,000 \\
6,000 \\
4,000 \\
7,000 \\
8,000 \\
5,000 \\
4,000 \\
7,000 \\
3,600 \\
5,000\end{array}$ & $\begin{array}{r}5,000 \\
1,500 \\
900 \\
510 \\
600 \\
3,000 \\
1,000 \\
2,000 \\
5,000 \\
1,000\end{array}$ \\
\hline $\begin{array}{l}18: 3: 2 \ldots \\
3: 3: 2 \ldots \\
2: 3: 2 \ldots \\
1: 3: 2 \ldots\end{array}$ & \begin{tabular}{l}
$\mathrm{MgO}-\mathrm{C}_{3} \mathrm{~T}_{2 \ldots} \ldots$ \\
\hdashline $\mathrm{do}$
\end{tabular} & $\begin{array}{l}1 / 2 \\
1 / 2 \\
1 / 2 \\
1 / 2\end{array}$ & $\begin{array}{l}1,625 \\
1,625 \\
1,650 \\
1,650\end{array}$ & $\begin{array}{l}15.8 \\
15.8 \\
16.0 \\
15.6\end{array}$ & $\begin{array}{l}.10 \\
.05 \\
.26 \\
.22\end{array}$ & $\begin{array}{l}15.2 \\
40.5 \\
42.8 \\
47.0\end{array}$ & $\begin{array}{l}16.9 \\
39.4 \\
42.8 \\
47.2\end{array}$ & $\begin{array}{l}41.6 \\
45.9\end{array}$ & $\begin{array}{r}400 \\
900 \\
1,300 \\
1,100\end{array}$ & $\begin{array}{l}3,800 \\
1,700 \\
1,300 \\
2,100\end{array}$ & $\begin{array}{l}2,600 \\
1,000 \\
1,800 \\
1,700\end{array}$ \\
\hline $\begin{array}{l}1: 1: 5 \\
1: 1: 9 \\
1: 3: 9 \\
3: 1: 3 \ldots \\
4: 1: 4 \\
4 \ldots\end{array}$ & $\begin{array}{l}\mathrm{MT}_{2} \text {-CT-TiO } \\
\text { do } \\
\mathrm{MT}-\mathrm{M}_{2} \mathrm{~T}-\mathrm{CT}\end{array}$ & $\begin{array}{l}1 \\
1 \\
1 \\
2 \\
2\end{array}$ & $\begin{array}{l}1,350 \\
1,350 \\
1,350 \\
1,500 \\
1,500\end{array}$ & $\begin{array}{l}16.0 \\
17.3 \\
17.3 \\
12.2 \\
12.3\end{array}$ & $\begin{array}{l}.06 \\
.20 \\
.01 \\
.18 \\
.06\end{array}$ & $\begin{array}{r}67 \\
94 \\
109 \\
44 \\
37\end{array}$ & $\begin{array}{r}66 \\
92 \\
106 \\
43 \\
37\end{array}$ & $\begin{array}{r}66 \\
90 \\
105 \\
43 \\
37\end{array}$ & $\begin{array}{r}800 \\
44 \\
86 \\
1,300 \\
10,000\end{array}$ & $\begin{array}{r}1,200 \\
126 \\
230 \\
10,000 \\
1,000\end{array}$ & $\begin{array}{r}2,000 \\
440 \\
1,500 \\
2,400 \\
2,000\end{array}$ \\
\hline $\begin{array}{l}9: 1: 3 \\
4: 1: 2 \ldots \\
3: 1: 2 \\
3: 2: 3 \ldots \\
2: 3: 1 \ldots \\
1: 4: 1 \ldots \\
\end{array}$ & $\begin{array}{l}\mathrm{M}_{2} \mathrm{~T}-\mathrm{MgO} \mathrm{O}-\mathrm{CT} \\
\mathrm{ddo} \\
\mathrm{dg} \text { do } \\
\mathrm{MgO}-\mathrm{C}_{3} \mathrm{~T}_{2}-\mathrm{CaO} \\
\end{array}$ & $\begin{array}{l}1 \\
1 \\
2 \\
1 \\
1 / 2 \\
1 / 2\end{array}$ & $\begin{array}{l}1,540 \\
1,550 \\
1,550 \\
1,550 \\
1,625 \\
1,650\end{array}$ & $\begin{array}{l}10.2 \\
12.4 \\
11.9 \\
12.0 \\
20.0 \\
21.0\end{array}$ & $\begin{array}{l}.10 \\
.10 \\
.09 \\
.13 \\
.06 \\
.00\end{array}$ & $\begin{array}{l}24 \\
41 \\
52 \\
77 \\
26 \\
30\end{array}$ & $\begin{array}{l}24 \\
40 \\
52 \\
77 \\
28 \\
29\end{array}$ & $\begin{array}{l}24 \\
40 \\
51 \\
76 \\
28 \\
27\end{array}$ & $\begin{array}{r}4,000 \\
1,500 \\
10,000 \\
6,000 \\
300 \\
600\end{array}$ & $\begin{array}{r}10,000 \\
10,000 \\
10,000 \\
10,000 \\
1,600 \\
2,000\end{array}$ & $\begin{array}{l}2,700 \\
2,600 \\
2,100 \\
700 \\
1,400 \\
1,900\end{array}$ \\
\hline \multicolumn{12}{|c|}{$\mathrm{M}: \mathrm{C}: \mathrm{S} \quad$ The system $\mathrm{MgO}-\mathrm{CaO}-\mathrm{SnO}_{2}$} \\
\hline $\begin{array}{l}2: 1: 2 \mathrm{~d}- \\
2: 6: 7 \ldots \\
4: 1: 1 \ldots \\
2: 1: 1 \ldots \\
1: 1: 1 \ldots \\
1: 2: 2 \ldots \\
\end{array}$ & $\begin{array}{l}\mathrm{M}_{2} \mathrm{~S}-\mathrm{CS} \\
\mathrm{MgO} \text { do } \\
\text { do }\end{array}$ & $\begin{array}{l}1 \\
1 \\
1 \\
1 \\
1 \\
1\end{array}$ & $\begin{array}{l}1,550 \\
1,550 \\
1,550 \\
1,550 \\
1,550 \\
1,550\end{array}$ & $\begin{array}{l}18.0 \\
19.5 \\
19.5 \\
21.0 \\
21.0 \\
22.2\end{array}$ & $\begin{array}{l}0.15 \\
.26 \\
.01 \\
.03 \\
.02 \\
.02\end{array}$ & $\begin{array}{l}11.0 \\
14.1 \\
14.0 \\
13.2 \\
14.3 \\
14.4\end{array}$ & $\begin{array}{l}10.8 \\
14.0 \\
14.0 \\
13.2 \\
14.3 \\
14.4\end{array}$ & $\begin{array}{l}10.7 \\
14.0 \\
14.0 \\
13.2 \\
14.3 \\
14.4\end{array}$ & $\begin{array}{l}1,100 \\
190 \\
4,000 \\
2,000 \\
3,000 \\
3,000\end{array}$ & $\begin{array}{r}770 \\
670 \\
10,000 \\
10,000 \\
10,000 \\
10,000\end{array}$ & $\begin{array}{r}410 \\
620 \\
2,000 \\
2,000 \\
1,000 \\
4,000\end{array}$ \\
\hline $\begin{array}{l}4: 2: 1 \mathrm{~d}_{-}- \\
2: 2: 1 \mathrm{C}^{-} \\
1: 2: 1 \mathrm{~d}-\ldots\end{array}$ & $\begin{array}{c}\mathrm{MgO}-\mathrm{C}_{2} \mathrm{~S} \\
\mathrm{do}\end{array}$ & $\begin{array}{l}1 \\
1 \\
1\end{array}$ & $\begin{array}{l}1,550 \\
1,550 \\
1,550\end{array}$ & $\begin{array}{l}20.1 \\
19.0 \\
21.5\end{array}$ & $\begin{array}{l}.00 \\
.41 \\
.00\end{array}$ & $\begin{array}{l}11.2 \\
10.6 \\
13.4\end{array}$ & $\begin{array}{l}11.0 \\
10.6 \\
13.4\end{array}$ & $\begin{array}{l}11.0 \\
10.6 \\
13.4\end{array}$ & $\begin{array}{l}300 \\
500 \\
200\end{array}$ & $\begin{array}{l}230 \\
850 \\
760\end{array}$ & $\begin{array}{l}360 \\
600 \\
760\end{array}$ \\
\hline \multicolumn{12}{|c|}{$\mathrm{C}: \mathrm{S}: \mathrm{T} \quad$ The system $\mathrm{CaO}-\mathrm{SnO}_{2}-\mathrm{TiO}_{2}$} \\
\hline $\begin{array}{l}3: 1: 3 \ldots \\
1: 3: 1 \\
1: 9: 1 \mathrm{~d}_{--}\end{array}$ & $\begin{array}{r}\mathrm{CT}-\mathrm{SnO}_{2} \ldots \ldots \\
\hdashline \text { do }\end{array}$ & $\begin{array}{l}1 \\
1 \\
1\end{array}$ & $\begin{array}{l}1,500 \\
1,550 \\
1,550\end{array}$ & $\begin{array}{l}16.8 \\
19.7 \\
18.0\end{array}$ & $\begin{array}{r}0.01 \\
.12 \\
.16\end{array}$ & $\begin{array}{r}106 \\
39 \\
27\end{array}$ & $\begin{array}{r}106 \\
39 \\
25\end{array}$ & $\begin{array}{c}106 \\
38 \\
-\end{array}$ & $\begin{array}{r}600 \\
30 \\
40\end{array}$ & $\begin{array}{r}2,000 \\
170 \\
30\end{array}$ & $\begin{array}{r}1,500 \\
230 \\
-\end{array}$ \\
\hline $\begin{array}{l}3: 1: 2 \ldots \\
2: 1: 1 \ldots \\
3: 2: 1 \ldots \\
5: 4: 1 \ldots \\
\end{array}$ & \begin{tabular}{|}
$\mathrm{CT}-\mathrm{CS}_{\ldots} \ldots$ \\
do \\
\hdashline do \\
\hdashline
\end{tabular} & $\begin{array}{l}1 \\
1 \\
1 \\
1\end{array}$ & $\begin{array}{l}1,500 \\
1,550 \\
1,550 \\
1,500\end{array}$ & $\begin{array}{l}17.9 \\
17.8 \\
16.8 \\
19.9\end{array}$ & $\begin{array}{l}.00 \\
.15 \\
.02 \\
.00\end{array}$ & $\begin{array}{l}84 \\
62 \\
38 \\
24\end{array}$ & $\begin{array}{l}84 \\
61 \\
38 \\
24\end{array}$ & $\begin{array}{l}84 \\
61 \\
37 \\
24\end{array}$ & $\begin{array}{l}2,800 \\
850 \\
2,000 \\
1,500\end{array}$ & $\begin{array}{l}5,000 \\
5,000 \\
4,000 \\
2,000\end{array}$ & $\begin{array}{r}800 \\
2,100 \\
2,000 \\
2,000\end{array}$ \\
\hline $\begin{array}{l}4: 1: 2 \mathrm{~d} \\
6: 3: 2 \mathrm{~d}-\ldots \\
9: 6: 2 \\
8: 1: 4 \mathrm{~d}^{-} \\
7: 2: 2 \mathrm{~d} \\
19: 8: 2 \mathrm{~d}\end{array}$ & $\begin{array}{l}\mathrm{C}_{3} \mathrm{~T}_{2}-\mathrm{CS}_{2} \\
\quad \text { do } \\
\mathrm{d}_{3} \mathrm{~T}_{2}-\mathrm{C}_{2} \mathrm{~S}_{2} \\
\mathrm{~d}\end{array}$ & $\begin{array}{l}1 \\
1 / 2 \\
1 \\
1 \\
1 \\
1\end{array}$ & $\begin{array}{l}1,550 \\
1,550 \\
1,500 \\
1,550 \\
1,550 \\
1,550\end{array}$ & $\begin{array}{l}21.0 \\
22.0 \\
21.5 \\
21.7 \\
23.7 \\
22.9\end{array}$ & $\begin{array}{l}.12 \\
.02 \\
.08 \\
.05 \\
.08 \\
.02\end{array}$ & $\begin{array}{l}45.2 \\
37.8 \\
30.6 \\
42 \\
35 \\
18\end{array}$ & $\begin{array}{l}44.9 \\
37.6 \\
30.6 \\
42 \\
34 \\
18\end{array}$ & $\begin{array}{l}37.4 \\
30.6 \\
35 \\
18\end{array}$ & $\begin{array}{r}210 \\
290 \\
7,000 \\
90 \\
55 \\
70\end{array}$ & $\begin{array}{r}470 \\
600 \\
10,000 \\
400 \\
70 \\
230\end{array}$ & $\begin{array}{r}380 \\
760 \\
170 \\
460\end{array}$ \\
\hline $\begin{array}{l}1: 3: 9 \\
2: 1: 4 \ldots \\
2: 2: 3 \ldots\end{array}$ & $\begin{array}{l}\mathrm{CT}-\mathrm{SnO}_{2}-\mathrm{TiO}_{2} \\
\mathrm{do}\end{array}$ & $\begin{array}{l}1 \\
1 \\
1\end{array}$ & $\begin{array}{l}1,430 \\
1,500 \\
1,500\end{array}$ & $\begin{array}{l}15.0 \\
16.8 \\
15.0\end{array}$ & $\begin{array}{l}.02 \\
.09 \\
.00\end{array}$ & $\begin{array}{r}76 \\
111 \\
82\end{array}$ & $\begin{array}{r}76 \\
110 \\
81\end{array}$ & $\begin{array}{r}76 \\
110 \\
81\end{array}$ & $\begin{array}{r}200 \\
2,000 \\
1,700\end{array}$ & $\begin{array}{l}1,300 \\
3,000 \\
2,300\end{array}$ & $\begin{array}{r}680 \\
2.200 \\
2,400\end{array}$ \\
\hline $\begin{array}{l}3: 3: 2 \\
3: 2: 2 \mathrm{~d}\end{array}$ & $\begin{array}{l}\text { CT-CS- } \mathrm{SnO}_{2} \ldots \ldots \\
\text { do }\end{array}$ & $\begin{array}{l}1 \\
1\end{array}$ & $\begin{array}{l}1,500 \\
1,550\end{array}$ & $\begin{array}{l}17.0 \\
16.3\end{array}$ & $\begin{array}{l}.16 \\
.04\end{array}$ & $\begin{array}{l}62 \\
67\end{array}$ & $\begin{array}{l}59 \\
67\end{array}$ & $\begin{array}{l}59 \\
67\end{array}$ & $\begin{array}{r}400 \\
1,000\end{array}$ & $\begin{array}{l}1,500 \\
2,000\end{array}$ & $\begin{array}{r}1,600 \\
440\end{array}$ \\
\hline $\begin{array}{l}27: 18: 2 \mathrm{~d} \ldots \\
6: 3: 1 \mathrm{~d} \ldots\end{array}$ & $\begin{array}{l}\mathrm{C}_{3} \mathrm{~T}_{2}-\mathrm{CS}-\mathrm{C}_{2} \mathrm{~S} \\
\mathrm{do}\end{array}$ & $\begin{array}{l}1 \\
1\end{array}$ & $\begin{array}{l}1,550 \\
1,550\end{array}$ & $\begin{array}{l}23.1 \\
23.5\end{array}$ & $\begin{array}{l}.00 \\
.00\end{array}$ & $\begin{array}{l}17.5 \\
23.7\end{array}$ & $\begin{array}{l}17.3 \\
23.5\end{array}$ & $\begin{array}{l}17.3 \\
23.5\end{array}$ & $\begin{array}{l}150 \\
220\end{array}$ & $\begin{array}{l}320 \\
470\end{array}$ & $\begin{array}{l}340 \\
400\end{array}$ \\
\hline
\end{tabular}


TABLE 13. Results of dielectric testing-Continued

\begin{tabular}{|c|c|c|c|c|c|c|c|c|c|c|c|}
\hline \multirow{2}{*}{ Mole ratio } & \multirow{2}{*}{ Binary join, ternary field, or quaternary volume } & \multicolumn{2}{|c|}{ Heat treatment a } & \multirow{2}{*}{ Shrink- } & \multirow{2}{*}{$-\begin{array}{c}\text { Absorp- } \\
\text { tion }\end{array}$} & \multicolumn{3}{|c|}{$\begin{array}{l}\text { Dielectric constant, } K, \\
\text { at } 25^{\circ} \mathrm{C} \text { and - }\end{array}$} & \multicolumn{3}{|c|}{$\begin{array}{c}\text { Reciprocal, } O \text {, of power factor } \\
\text { at } 25^{\circ} \mathrm{C} \text { and- }\end{array}$} \\
\hline & & Time & $\begin{array}{l}\text { Temper- } \\
\text { ature }\end{array}$ & & & $50 \mathrm{kc}$ & $1 \mathrm{Mc}$ & $20 \mathrm{Mc}$ & $50 \mathrm{kc}$ & $1 \mathrm{Me}$ & $20 \mathrm{Mc}$ \\
\hline \multicolumn{12}{|l|}{$\mathrm{M}: \mathrm{C}: \mathrm{S}: \mathrm{T}$} \\
\hline $\begin{array}{l}8: 1: 4: 1 \mathrm{~b}- \\
4: 1: 2: 1 \mathrm{~b}^{--} \\
2: 1: 1: 1 \\
2: 2: 1: 2 \\
2: 3: 1: 3 \mathrm{~d}--- \\
2: 5: 1: 5 \mathrm{~b}- \\
2: 9: 1: 9 \mathrm{~b}^{---}\end{array}$ & $\begin{array}{l}\mathrm{M}_{2} \mathrm{~S}-\mathrm{CT} \\
\mathrm{do} \\
\mathrm{do}\end{array}$ & $\begin{array}{l}1 \\
1 \\
1 \\
1 \\
1 \\
1 \\
1\end{array}$ & $\begin{array}{l}1,500 \\
1,500 \\
1,550 \\
1,550 \\
1,550 \\
1,500 \\
1,500\end{array}$ & $\begin{array}{l}20.2 \\
16.4 \\
13.9 \\
15.0 \\
13.4 \\
12.8\end{array}$ & $\begin{array}{r}0.18 \\
.43 \\
.34 \\
.23 \\
.13 \\
.16 \\
.26\end{array}$ & $\begin{array}{l}14.8 \\
17.4 \\
29.6 \\
53.1 \\
68.1 \\
102 \\
118\end{array}$ & $\begin{array}{l}14.7 \\
17.4 \\
29.6 \\
53.0 \\
68.0 \\
102 \\
118\end{array}$ & $\begin{array}{l}14.7 \\
17.4 \\
29.6 \\
52.9 \\
68.0 \\
102 \\
118\end{array}$ & $\begin{array}{r}2,000 \\
2,000 \\
3,000 \\
5,000 \\
2,000 \\
1,000 \\
\mathbf{1 8 0}\end{array}$ & $\begin{array}{r}7,000 \\
4,000 \\
7,000 \\
5,000 \\
6,000 \\
4,000 \\
250\end{array}$ & $\begin{array}{l}2,000 \\
3,000 \\
4,000 \\
2,000 \\
800 \\
2,000 \\
1,000\end{array}$ \\
\hline $\begin{array}{l}2: 1: 1: 2 \\
2: 2: 1: 3 \\
2: 9: 1: 10 \mathrm{~b} \\
1: 3: 1: 2 \mathrm{~b} \\
2: 2: 1: 1 \\
3: 4: 3: 1 \\
2: 5: 4: 1\end{array}$ & 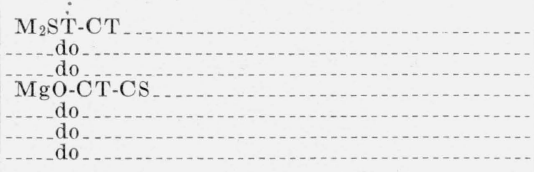 & $\begin{array}{l}1 \\
1 \\
1 \\
1 \\
1 \\
1 \\
1\end{array}$ & $\begin{array}{l}1,450 \\
1,450 \\
1,500 \\
1,500 \\
1,550 \\
1,550 \\
1,550\end{array}$ & $\begin{array}{l}14.0 \\
12.8 \\
11.8 \\
17.1 \\
16.8 \\
14.3 \\
19.3\end{array}$ & $\begin{array}{l}.17 \\
.05 \\
.00 \\
.05 \\
.12 \\
.23 \\
.05\end{array}$ & $\begin{array}{c}32.8 \\
56.0 \\
109 \\
72.7 \\
33.7 \\
22.1 \\
22.3\end{array}$ & $\begin{array}{c}32.6 \\
56.0 \\
109 \\
72.7 \\
33.7 \\
22.1 \\
22.2\end{array}$ & $\begin{array}{r}32.6 \\
56.0 \\
108 \\
72.7 \\
33.7 \\
22.1 \\
22.2\end{array}$ & $\begin{array}{l}2,000 \\
3,000 \\
1,000 \\
7,000 \\
3,000 \\
3,000 \\
2,000\end{array}$ & $\begin{array}{l}4,000 \\
1,700 \\
3,000 \\
4,000 \\
3,000 \\
6,000 \\
5,000\end{array}$ & $\begin{array}{r}1,800 \\
560 \\
2,000 \\
500 \\
2,000 \\
1,000 \\
700\end{array}$ \\
\hline $\begin{array}{l}2: 2: 2: 1 \\
3: 1: 1: 2 \\
5: 1: 2: 3 \\
5: 1: 1: 3 \\
5: 1: 1: 2\end{array}$ & 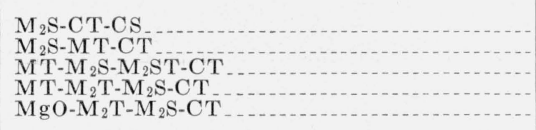 & $\begin{array}{l}1 \\
1 \\
1 \\
1 \\
1\end{array}$ & $\begin{array}{l}1,550 \\
1,400 \\
1,450 \\
1,450 \\
1,550\end{array}$ & $\begin{array}{l}19.4 \\
11.5 \\
11.6 \\
10.4 \\
14.2\end{array}$ & $\begin{array}{l}.12 \\
.30 \\
.66 \\
.10 \\
.40\end{array}$ & $\begin{array}{l}27.7 \\
27.6 \\
23.7 \\
24.0 \\
27.2\end{array}$ & $\begin{array}{l}27.6 \\
27.4 \\
23.6 \\
23.9 \\
27.1\end{array}$ & $\begin{array}{l}27.5 \\
27.4 \\
23.6 \\
23.9 \\
27.0\end{array}$ & $\begin{array}{r}420 \\
1,000 \\
40 \\
3,000 \\
4,000\end{array}$ & $\begin{array}{r}5,000 \\
4,000 \\
360 \\
4,000 \\
7,000\end{array}$ & $\begin{array}{r}640 \\
1,500 \\
800 \\
5,000 \\
580\end{array}$ \\
\hline $\begin{array}{l}4: 3: 2: 2 \\
1: 5: 1: 3 \\
1: 6: 2: 2 \\
1: 6: 1: 2 \mathrm{~b} \\
1: 15: 4: 4 \\
\end{array}$ & $\begin{array}{l}\mathrm{MgO}-\mathrm{M}_{2} \mathrm{~S}-\mathrm{CS}-\mathrm{CT} \\
\mathrm{MgO}-\mathrm{CS}-\mathrm{CT}-\mathrm{C}_{3} \mathrm{~T}_{2} \\
\mathrm{MgO}-\mathrm{C}_{2} \mathrm{~S}-\mathrm{CS}-\mathrm{C}_{3} \mathrm{~T}_{2} \\
\mathrm{MgO}-\mathrm{CaO}-\mathrm{C}_{2} \mathrm{~S}-\mathrm{C}_{3} \mathrm{~T}_{2} \\
\quad\end{array}$ & $\begin{array}{l}1 \\
1 \\
1 \\
1 \\
1\end{array}$ & $\begin{array}{l}1,550 \\
1,550 \\
1,550 \\
1,500 \\
1,500\end{array}$ & $\begin{array}{l}16.3 \\
22.5 \\
17.8 \\
22.2 \\
22.6\end{array}$ & $\begin{array}{l}.44 \\
.35 \\
.29 \\
.18 \\
.04\end{array}$ & $\begin{array}{l}41.5 \\
45.8 \\
34.4 \\
37.3 \\
30.6\end{array}$ & $\begin{array}{l}41.4 \\
45.8 \\
34.2 \\
37.3 \\
30.2\end{array}$ & $\begin{array}{l}41.4 \\
45.3 \\
34.1 \\
37.1 \\
29.7\end{array}$ & $\begin{array}{r}3,000 \\
140 \\
500 \\
430 \\
90\end{array}$ & $\begin{array}{r}4,500 \\
280 \\
500 \\
900 \\
130\end{array}$ & $\begin{array}{r}1,300 \\
500 \\
330 \\
380 \\
280\end{array}$ \\
\hline
\end{tabular}

a Each specimen had been calcined once prior to the recorded heat treatment.

b A commercial grade of $\mathrm{CaO} \cdot \mathrm{TiO}_{2}$ was used in the preparation of this specimen.

c Periclase of 96-percent purity was used in the preparation of this specimen.

d One percent of $\mathrm{Fe}_{2} \mathrm{O}_{3}$ was added to the specimen.

TABLE 14. Variation of dielectric constant with temperature

\begin{tabular}{|c|c|c|c|c|c|c|c|c|c|c|c|c|c|c|}
\hline \multirow{2}{*}{ Mole ratio } & \multirow{2}{*}{$\begin{array}{l}\text { Binary join, ternary field, or } \\
\text { quaternary volume }\end{array}$} & \multicolumn{12}{|c|}{ Value of $K$ at $1 \mathrm{Mc}$ and- } & \multirow{2}{*}{$\begin{array}{l}\text { Average } \\
\text { tempera- } \\
\text { ture co- } \\
\text { efficient } \\
\text { of } K \text { over } \\
\text { range in- } \\
\text { dicated }\end{array}$} \\
\hline & & $-50^{\circ} \mathrm{C}$ & $0^{\circ} \mathrm{C}$ & $25^{\circ} \mathrm{C}$ & $50^{\circ} \mathrm{C}$ & $75^{\circ} \mathrm{C}$ & $100^{\circ} \mathrm{C}$ & $125^{\circ} \mathrm{C}$ & $150^{\circ} \mathrm{C}$ & $175^{\circ} \mathrm{C}$ & $200^{\circ} \mathrm{C}$ & $225^{\circ} \mathrm{C}$ & $250^{\circ} \mathrm{C}$ & \\
\hline \multicolumn{15}{|c|}{ The system $\mathrm{MgO}-\mathrm{CaO}-\mathrm{TiO}_{2}$} \\
\hline $\begin{array}{l}9: 1: 10 \\
4: 1: 5 \\
2: 1: 3 \\
1: 1: 2\end{array}$ & \begin{tabular}{l} 
MT-CT $\ldots \ldots$ \\
\hdashline do \\
\hdashline do
\end{tabular} & $\begin{array}{l}24.1 \\
38.9 \\
58.5 \\
87.1\end{array}$ & $\begin{array}{l}23.9 \\
37.6 \\
55.3 \\
81.9\end{array}$ & $\begin{array}{l}23.7 \\
37.1 \\
54.1 \\
78.5\end{array}$ & $\begin{array}{l}23.5 \\
36.4 \\
52.7 \\
75.2\end{array}$ & $\begin{array}{l}23.4 \\
35.8 \\
51.5 \\
72.7\end{array}$ & $\begin{array}{l}23.4 \\
35.3 \\
50.3 \\
70.5\end{array}$ & $\begin{array}{l}23.3 \\
34.9 \\
49.4 \\
68.3\end{array}$ & $\begin{array}{l}23.3 \\
34.5 \\
48.6 \\
66.6\end{array}$ & $\begin{array}{l}23.2 \\
34.1 \\
47.8 \\
65.2\end{array}$ & $\begin{array}{l}23.2 \\
33.8 \\
47.0 \\
63.7\end{array}$ & $\begin{array}{l}23.2 \\
33.5 \\
46.4 \\
62.5\end{array}$ & $\begin{array}{l}23.2 \\
33.3 \\
45.9 \\
61.4\end{array}$ & $\begin{array}{r}p p m /{ }^{\circ} C \\
-130 \\
-520 \\
-800 \\
-1,080\end{array}$ \\
\hline $\begin{array}{l}38: 1: 20 \\
6: 1: 4 \\
2: 1: 2 \\
2: 2: 3 \\
2: 7: 8 \\
2\end{array}$ & $\begin{array}{r}\mathrm{M}_{2} \mathrm{~T}-\mathrm{CT} \\
\quad \text { do do } \\
\text { do }\end{array}$ & $\begin{array}{l}33.1 \\
66.8 \\
104 \\
151\end{array}$ & $\begin{array}{r}32.5 \\
62.4 \\
97.6 \\
141\end{array}$ & $\begin{array}{r}17.7 \\
32.0 \\
60.6 \\
92.7 \\
135\end{array}$ & $\begin{array}{r}17.7 \\
31.6 \\
58.2 \\
88.6 \\
128\end{array}$ & $\begin{array}{r}17.7 \\
31.0 \\
56.4 \\
85.4 \\
123\end{array}$ & $\begin{array}{r}17.7 \\
30.6 \\
54.7 \\
82.4 \\
119\end{array}$ & $\begin{array}{r}17.7 \\
30.2 \\
53.2 \\
79.8 \\
114\end{array}$ & $\begin{array}{r}17.7 \\
29.8 \\
52.0 \\
77.7 \\
111\end{array}$ & $\begin{array}{r}17.8 \\
29.4 \\
50.9 \\
75.6 \\
107\end{array}$ & $\begin{array}{c}17.8 \\
29.1 \\
49.8 \\
73.4 \\
104\end{array}$ & $\begin{array}{r}17.8 \\
28.9 \\
48.9 \\
72.0 \\
102\end{array}$ & $\begin{array}{r}18.2 \\
28.7 \\
48.2 \\
70.1 \\
100\end{array}$ & $\begin{array}{r}+280 \\
-480 \\
-1,100 \\
-1,300 \\
-1,360\end{array}$ \\
\hline $\begin{array}{l}4: 1: 1 \\
2: 1: 1 \\
2: 1: 1 \mathrm{~b} \\
1: 1: 1 \\
2: 3: 3 \mathrm{~b} \\
1: 2: 2 \\
1: 3: 3 \mathrm{~b}\end{array}$ & $\begin{array}{l}\mathrm{MgO}-\mathrm{CT} \\
\text { do } \\
\text { do } \\
\text { do }\end{array}$ & $\begin{array}{l}46.1 \\
79.5 \\
77 \\
108 \\
123 \\
142 \\
146\end{array}$ & $\begin{array}{c}44.3 \\
74.5 \\
72 \\
100 \\
113 \\
133 \\
135\end{array}$ & $\begin{array}{l}43.1 \\
72.7 \\
69 \\
97.6 \\
109 \\
128 \\
129\end{array}$ & $\begin{array}{l}42.0 \\
70.2 \\
67 \\
93.7 \\
106 \\
123 \\
125\end{array}$ & $\begin{array}{l}41.0 \\
68.2 \\
65 \\
90.4 \\
103 \\
119 \\
121\end{array}$ & $\begin{array}{l}40.2 \\
66.3 \\
64 \\
87.6 \\
100 \\
115 \\
117\end{array}$ & $\begin{array}{l}39.4 \\
64.7 \\
62 \\
84.9 \\
97 \\
112 \\
114\end{array}$ & $\begin{array}{l}38.8 \\
63.3 \\
61 \\
82.9 \\
95 \\
109 \\
111\end{array}$ & $\begin{array}{c}38.2 \\
62.0 \\
60 \\
80.8 \\
92 \\
106 \\
108\end{array}$ & $\begin{array}{c}37.8 \\
60.9 \\
59 \\
78.9 \\
91 \\
104 \\
106\end{array}$ & $\begin{array}{l}37.3 \\
60.1 \\
58 \\
77.7 \\
89 \\
102 \\
103\end{array}$ & $\begin{array}{c}37.1 \\
(\mathrm{a}) \\
57 \\
(\mathrm{a}) \\
88 \\
(\mathrm{a}) \\
102\end{array}$ & $\begin{array}{r}-720 \\
-1,010 \\
-1,000 \\
-1,090 \\
-1,100 \\
-1,190 \\
-1,180\end{array}$ \\
\hline $\begin{array}{l}18: 3: 2 \\
2: 3: 2 \\
1: 3: 9 \\
4: 1: 4 \\
4\end{array}$ & $\begin{array}{l}\mathrm{MgO}-\mathrm{C}_{3} \mathrm{~T}_{2} \\
\quad \mathrm{do} \\
\mathrm{MT}_{2}-\mathrm{CT}_{\mathrm{T}} \mathrm{TiO} \mathrm{T}_{2} \\
\mathrm{MT}-\mathrm{M}_{2} \mathrm{~T}-\mathrm{CT}\end{array}$ & $\begin{array}{c}18.4 \\
45.4 \\
122 \\
38.8\end{array}$ & $\begin{array}{r}17.4 \\
44.8 \\
114 \\
37.7\end{array}$ & $\begin{array}{r}17.4 \\
44.6 \\
111 \\
36.9\end{array}$ & $\begin{array}{c}17.3 \\
44.5 \\
108 \\
36.2\end{array}$ & $\begin{array}{c}17.3 \\
43.8 \\
105 \\
35.7\end{array}$ & $\begin{array}{c}17.3 \\
43.6 \\
103 \\
35.1\end{array}$ & $\begin{array}{c}17.3 \\
43.4 \\
100 \\
34.6\end{array}$ & $\begin{array}{l}17.4 \\
43.2 \\
97.6 \\
34.3\end{array}$ & $\begin{array}{l}17.5 \\
43.1 \\
95.5 \\
33.9\end{array}$ & $\begin{array}{l}17.6 \\
43.3 \\
93.4 \\
33.5\end{array}$ & $\begin{array}{l}17.7 \\
43.5 \\
91.6 \\
33.2\end{array}$ & $\begin{array}{l}\text { (a) } \\
\text { (a) } \\
89.6 \\
33.0\end{array}$ & $\begin{array}{r}-1,020 \\
-540\end{array}$ \\
\hline $\begin{array}{l}3: 2: 3 \\
2: 3: 1 \\
1: 4: 1\end{array}$ & $\begin{array}{l}\mathrm{M}_{2} \mathrm{~T}-\mathrm{MgO}-\mathrm{CT} \\
\mathrm{MgO}-\mathrm{C}_{3} \mathrm{~T}_{2}-\mathrm{CaO}\end{array}$ & $\begin{array}{l}84.4 \\
31.0 \\
29.3\end{array}$ & $\begin{array}{l}80.4 \\
30.8 \\
29.2\end{array}$ & $\begin{array}{l}76.7 \\
30.7 \\
29.1\end{array}$ & $\begin{array}{l}73.4 \\
30.8 \\
29.0\end{array}$ & $\begin{array}{l}71.0 \\
30.7 \\
28.9\end{array}$ & $\begin{array}{l}68.9 \\
30.6 \\
28.9\end{array}$ & $\begin{array}{l}66.8 \\
30.6 \\
28.9\end{array}$ & $\begin{array}{l}65.0 \\
30.6 \\
29.0\end{array}$ & $\begin{array}{l}63.0 \\
30.7 \\
29.2\end{array}$ & $\begin{array}{l}62.2 \\
30.8 \\
29.4\end{array}$ & $\begin{array}{l}61.2 \\
31.1 \\
(\mathrm{a})\end{array}$ & $\begin{array}{c}59.9 \\
(\mathrm{a}) \\
--\end{array}$ & $\begin{array}{r}-1,130 \\
- \\
-\end{array}$ \\
\hline
\end{tabular}

See footnotes at end of table. 
TABLE 14. Variation of dielectric constant with temperature-Continued

\begin{tabular}{|c|c|c|c|c|c|c|c|c|c|c|c|c|c|c|}
\hline \multirow{2}{*}{ Mole ratio } & \multirow{2}{*}{$\begin{array}{l}\text { Binary join, ternary field, or } \\
\text { quaternary volume }\end{array}$} & \multicolumn{12}{|c|}{ Value of $K$ at 1 Me and- } & \multirow{2}{*}{$\begin{array}{l}\text { Average } \\
\text { tempera- } \\
\text { ture co- } \\
\text { efficient } \\
\text { of } K \text { over } \\
\text { range in- } \\
\text { dicated }\end{array}$} \\
\hline & & $-50^{\circ} \mathrm{C}$ & $0^{\circ} \mathrm{C}$ & $25^{\circ} \mathrm{C}$ & $50^{\circ} \mathrm{C}$ & $75^{\circ} \mathrm{C}$ & $100^{\circ} \mathrm{C}$ & $125^{\circ} \mathrm{C}$ & $150^{\circ} \mathrm{C}$ & $175^{\circ} \mathrm{C}$ & $200^{\circ} \mathrm{C}$ & $225^{\circ} \mathrm{C}$ & $250^{\circ} \mathrm{C}$ & \\
\hline \multicolumn{15}{|c|}{ The system $\mathrm{MgO}-\mathrm{CaO}-\mathrm{SnO}_{2}$} \\
\hline $\begin{array}{l}2: 6: 7 \\
4: 1: 1 \\
2: 1: 1 \\
1: 1: 1 \\
1: 11^{\mathrm{e}}-\cdots \\
1: 2: 2\end{array}$ & $\begin{array}{l}\mathrm{M}_{2} \mathrm{~S}-\mathrm{CS} \\
\mathrm{MgO}-\mathrm{CS} \\
\mathrm{do} \\
\\
\end{array}$ & $\begin{array}{l}13.7 \\
13.9 \\
13.2 \\
14.2 \\
14.2 \\
14.3\end{array}$ & $\begin{array}{l}13.9 \\
14.0 \\
13.2 \\
14.3 \\
14.3 \\
14.3\end{array}$ & $\begin{array}{l}13.9 \\
14.0 \\
13.3 \\
14.3 \\
14.3 \\
14.3\end{array}$ & $\begin{array}{l}14.0 \\
14.0 \\
13.3 \\
14.4 \\
14.4 \\
14.4\end{array}$ & $\begin{array}{l}14.1 \\
14.2 \\
13.3 \\
14.4 \\
14.4 \\
14.4\end{array}$ & $\begin{array}{l}14.1 \\
14.3 \\
13.3 \\
14.5 \\
14.4 \\
14.4\end{array}$ & $\begin{array}{l}14.1 \\
14.3 \\
13.3 \\
14.5 \\
14.4 \\
14.4\end{array}$ & $\begin{array}{l}\text { 14. } 1 \\
14.3 \\
13.4 \\
14.5 \\
14.5 \\
14.5\end{array}$ & $\begin{array}{l}14.1 \\
14.4 \\
13.4 \\
14.6 \\
14.5 \\
14.5\end{array}$ & $\begin{array}{l}14.1 \\
14.4 \\
13.5 \\
14.6 \\
14.5 \\
14.6\end{array}$ & $\begin{array}{l}14.1 \\
14.5 \\
13.5 \\
14.7 \\
14.6 \\
14.7\end{array}$ & $\begin{array}{l}14.2 \\
14.5 \\
13.6 \\
14.7 \\
14.7 \\
14.7\end{array}$ & $\begin{array}{l}+120 \\
+140 \\
+100 \\
+120 \\
+120 \\
+90\end{array}$ \\
\hline $\begin{array}{l}4: 2: 1{ }^{\mathrm{c}}- \\
2: 2: 1 \\
1: 2: 1{ }^{\mathrm{c}}\end{array}$ & $\begin{array}{l}\mathrm{MgO}-\mathrm{C}_{2} \mathrm{~S} \\
\mathrm{ddo}\end{array}$ & $\begin{array}{r}10.9 \\
9.9 \\
13.3\end{array}$ & $\begin{array}{l}11.0 \\
10.5 \\
13.4\end{array}$ & $\begin{array}{l}11.0 \\
10.5 \\
13.4\end{array}$ & $\begin{array}{l}11.2 \\
10.5 \\
13.5\end{array}$ & $\begin{array}{l}11.2 \\
10.6 \\
13.5\end{array}$ & $\begin{array}{l}11.3 \\
10.6 \\
13.6\end{array}$ & $\begin{array}{l}11.4 \\
10.6 \\
13.6\end{array}$ & $\begin{array}{l}11.4 \\
10.6 \\
13.7\end{array}$ & $\begin{array}{l}11.4 \\
10.7 \\
13.8\end{array}$ & $\begin{array}{l}11.5 \\
10.7 \\
14.0\end{array}$ & $\begin{array}{l}11.5 \\
10.7 \\
14.2\end{array}$ & $\begin{array}{l}11.6 \\
10.8 \\
14.4\end{array}$ & $\begin{array}{l}+210 \\
+290 \\
+260\end{array}$ \\
\hline \multicolumn{15}{|l|}{$\mathrm{C}: \mathrm{S}: \mathrm{T}$} \\
\hline $\begin{array}{l}1: 3: 1 \ldots \\
1: 9: 1 \mathrm{c} \\
3: 1: 2 \ldots \\
2: 1: 1 \\
3: 2: 1 \ldots \\
5: 4: 1 \ldots \\
5\end{array}$ & $\begin{array}{l}\mathrm{CT}-\mathrm{SnO}_{2} \ldots \\
\mathrm{CT}-\mathrm{CS} \\
\mathrm{dd} \\
\mathrm{dd}\end{array}$ & $\begin{array}{l}39.5 \\
24.9 \\
91 \\
-- \\
24.6\end{array}$ & $\begin{array}{l}37.8 \\
25.3 \\
86 \\
-\cdots \\
24.4\end{array}$ & $\begin{array}{l}37.1 \\
25.4 \\
84.8 \\
60.8 \\
37.8 \\
24.3\end{array}$ & $\begin{array}{l}36.0 \\
(\mathrm{a}) \\
81 \\
59.1 \\
37.3 \\
24.2\end{array}$ & $\begin{array}{l}35.9 \\
79 \\
57.6 \\
36.8 \\
24.1\end{array}$ & $\begin{array}{l}35.2 \\
77 . \\
56.3 \\
36.3 \\
24.0\end{array}$ & $\begin{array}{l}34.8 \\
76 \\
55.3 \\
35.9 \\
24.0\end{array}$ & $\begin{array}{l}34.5 \\
74 . \\
54.4 \\
35.5 \\
23.9\end{array}$ & $\begin{array}{l}34.0 \\
72 \\
53.4 \\
35.3 \\
23.9\end{array}$ & $\begin{array}{l}33.8 \\
71 . \\
52.7 \\
34.9 \\
23.8\end{array}$ & $\begin{array}{l}33.6 \\
70 \\
51.9 \\
34.7 \\
23.8\end{array}$ & $\begin{array}{l}33.4 \\
69 \\
51.4 \\
34.4 \\
23.8\end{array}$ & $\begin{array}{l}-550 \\
-920 \\
-750 \\
-420 \\
-110\end{array}$ \\
\hline $\begin{array}{l}4: 1: 2^{\mathrm{c}} \\
6: 3: 2^{\mathrm{c}} \\
8: 1: 4^{\mathrm{c}} \mathrm{c} \\
7: 2: 2^{\mathrm{c}}- \\
19: 8: 2^{\mathrm{c}}\end{array}$ & \begin{tabular}{l}
$\mathrm{C}_{3} \mathrm{~T}_{2}-\mathrm{CS}$ \\
\hdashline $\mathrm{C}_{3} \mathrm{~T}_{2}-\mathrm{C}_{2} \mathrm{~S}$ \\
do
\end{tabular} & $\begin{array}{l}46.1 \\
38.6 \\
42.2 \\
35.0 \\
17.6\end{array}$ & $\begin{array}{l}45.3 \\
37.9 \\
41.8 \\
34.9 \\
17.7\end{array}$ & $\begin{array}{l}44.9 \\
37.6 \\
41.7 \\
34.9 \\
17.7\end{array}$ & $\begin{array}{l}44.4 \\
37.1 \\
41.5 \\
\text { (a) } \\
17.8\end{array}$ & $\begin{array}{l}44.2 \\
36.9 \\
41.4 \\
17.9\end{array}$ & $\begin{array}{l}44.1 \\
36.7 \\
41.4 \\
\overline{18.1}\end{array}$ & $\begin{array}{l}43.8 \\
36.5 \\
41.3 \\
18.3\end{array}$ & \begin{tabular}{l}
43.7 \\
36.5 \\
41.3 \\
\hdashline$(\mathrm{a})$
\end{tabular} & \begin{tabular}{c}
43.6 \\
36.4 \\
$(\mathrm{a})$ \\
\hdashline
\end{tabular} & $\begin{array}{l}(\mathrm{a}) \\
36.4 \\
-\cdots \\
-\cdots\end{array}$ & $\begin{array}{l}-(\mathrm{a}) \\
-\cdots \\
-\cdots\end{array}$ & $\begin{array}{l}-\cdots \\
-\cdots \\
-\cdots \\
-\cdots\end{array}$ & $\begin{array}{l}-250 \\
-240 \\
-110 \\
+220\end{array}$ \\
\hline $\begin{array}{l}1: 3: 9 \\
2: 2: 3 \\
2: 1: 4\end{array}$ & $\begin{array}{c}\mathrm{CT}-\mathrm{SnO}_{2}-\mathrm{TiO}_{2} \\
\mathrm{do}\end{array}$ & $\begin{array}{l}82 \\
- \\
-\end{array}$ & $\begin{array}{l}78 \\
-\cdots \\
--\end{array}$ & $\begin{array}{l}76 \\
81.2 \\
110\end{array}$ & $\begin{array}{c}74 \\
78.6 \\
107\end{array}$ & $\begin{array}{l}72 \\
76.5 \\
103\end{array}$ & $\begin{array}{l}71 \\
74.3 \\
99.5\end{array}$ & $\begin{array}{l}69 \\
72.7 \\
97.1\end{array}$ & $\begin{array}{l}68 \\
71.2 \\
94.7\end{array}$ & $\begin{array}{l}67 \\
69.3 \\
92.0\end{array}$ & $\begin{array}{l}65 \\
68.0 \\
90.0\end{array}$ & $\begin{array}{l}64 \\
66.7 \\
88.4\end{array}$ & $\begin{array}{l}(\mathrm{a}) \\
65.2 \\
86.0\end{array}$ & $\begin{array}{r}-900 \\
-970 \\
-1,090\end{array}$ \\
\hline $\begin{array}{l}3: 2: 2^{\mathrm{c}} \ldots \\
3: 3: 2 \ldots\end{array}$ & $\mathrm{CT}-\mathrm{CS}-\mathrm{SnO}_{2} \ldots$ & $\begin{array}{l}71.5 \\
56.0\end{array}$ & $\begin{array}{l}68.5 \\
54.0\end{array}$ & $\begin{array}{l}67.0 \\
52.0\end{array}$ & $\begin{array}{l}65.1 \\
50.0\end{array}$ & $\begin{array}{l}63.6 \\
49.5\end{array}$ & $\begin{array}{l}62.5 \\
48.5\end{array}$ & $\begin{array}{l}61.4 \\
47.5\end{array}$ & $\begin{array}{l}60.3 \\
47.0\end{array}$ & $\begin{array}{l}59.3 \\
46.5\end{array}$ & $\begin{array}{l}58.5 \\
46.0\end{array}$ & $\begin{array}{l}57.8 \\
46.6\end{array}$ & $\underset{(\mathrm{a})}{57.2}$ & $\begin{array}{l}-740 \\
-670\end{array}$ \\
\hline $\begin{array}{l}27: 18: 2 \mathrm{c} \\
6: 3: 1 \mathrm{c}^{\mathrm{c}} \ldots\end{array}$ & $\mathrm{C}_{3} \mathrm{~T}_{2}-\mathrm{CS}-\mathrm{C}_{2} \mathrm{~S}$ & $\begin{array}{l}17.2 \\
23.8\end{array}$ & $\begin{array}{l}17.3 \\
23.6\end{array}$ & $\begin{array}{l}17.3 \\
23.5\end{array}$ & $\begin{array}{l}17.4 \\
23.5\end{array}$ & $\begin{array}{l}17.4 \\
23.5\end{array}$ & $\begin{array}{l}17.6 \\
23.4\end{array}$ & $\begin{array}{l}17.7 \\
23.6\end{array}$ & $\begin{array}{l}17.8 \\
23.7\end{array}$ & $\begin{array}{l}18.0 \\
23.8\end{array}$ & $\begin{array}{l}18.1 \\
23.9\end{array}$ & $\begin{array}{l}18.4 \\
24.1\end{array}$ & $\begin{array}{l}18.6 \\
24.5\end{array}$ & +260 \\
\hline \multicolumn{15}{|l|}{$\mathrm{M}: \mathrm{C}: \mathrm{S}: \mathrm{T}$} \\
\hline $\begin{array}{l}8: 1: 4: 1 \mathrm{~b} \\
4: 1: 2: 1 \mathrm{~b} \\
2: 1: 1: 1 \\
2: 2: 1: 2 \\
2: 5: 1: 5 \mathrm{~b} \\
2: 9: 1: 9 \mathrm{~b}\end{array}$ & $\begin{array}{l}\mathrm{M}_{2} \mathrm{~S}-\mathrm{CT} \\
\mathrm{do} \\
\text { do }\end{array}$ & $\begin{array}{l}15.0 \\
18.0 \\
32.0 \\
59 \\
116 \\
135\end{array}$ & $\begin{array}{l}14.8 \\
17.5 \\
30.4 \\
55 \\
106 \\
124\end{array}$ & $\begin{array}{l}14.7 \\
17.4 \\
29.6 \\
53 \\
102 \\
118\end{array}$ & $\begin{array}{l}14.6 \\
17.3 \\
29.1 \\
52 \\
99 \\
113\end{array}$ & $\begin{array}{l}14.5 \\
17.1 \\
28.4 \\
50 \\
96 \\
110\end{array}$ & $\begin{array}{l}14.4 \\
16.9 \\
27.9 \\
49 \\
93 \\
106\end{array}$ & $\begin{array}{l}14.4 \\
16.8 \\
27.5 \\
48 \\
90 \\
103\end{array}$ & $\begin{array}{l}14.3 \\
16.8 \\
27.0 \\
47 \\
88 \\
101\end{array}$ & $\begin{array}{l}14.3 \\
16.7 \\
26.6 \\
46 \\
84 \\
98\end{array}$ & $\begin{array}{l}14.3 \\
16.6 \\
26.3 \\
45 \\
83 \\
96\end{array}$ & $\begin{array}{l}14.3 \\
16.5 \\
26.0 \\
44 \\
82 \\
94\end{array}$ & $\begin{array}{l}14.2 \\
16.5 \\
25.8 \\
43 \\
81 \\
92\end{array}$ & $\begin{array}{r}-180 \\
-290 \\
-710 \\
-1,050 \\
-1,190 \\
-1,260\end{array}$ \\
\hline $\begin{array}{l}2: 1: 1: 2 \\
2: 2: 1: 3 \\
2: 9: 1: 10^{\mathrm{b}} \\
1: 3: 1: 2^{\mathrm{b}} \\
2: 2: 1: 1 \mathrm{c} \\
3: 4: 13 \\
2: 5: 1: 1 \\
2: 2: 2: 1 \\
\end{array}$ & $\begin{array}{c}\mathrm{M}_{2} \mathrm{ST}-\mathrm{CT} \\
\mathrm{MgO} \\
\mathrm{Mg}-\mathrm{CT}-\mathrm{CS} \\
\mathrm{M}_{2} \mathrm{~S}-\mathrm{CT}-\mathrm{CS} \\
\text { do }\end{array}$ & $\begin{array}{l}35.0 \\
62 \\
124 \\
80 \\
35.3 \\
22.5 \\
22.6 \\
29.1\end{array}$ & $\begin{array}{l}33.2 \\
58 \\
114 \\
75 \\
34.2 \\
22.2 \\
22.4 \\
28.1\end{array}$ & $\begin{array}{c}32.6 \\
56 \\
109 \\
73 \\
33.7 \\
22.1 \\
22.3 \\
27.6\end{array}$ & $\begin{array}{c}32.1 \\
54 \\
105 \\
71 \\
33.6 \\
22.0 \\
22.2 \\
27.2\end{array}$ & $\begin{array}{l}31.5 \\
53 \\
102 \\
69 \\
32.8 \\
21.8 \\
22.2 \\
26.8\end{array}$ & $\begin{array}{l}30.9 \\
52 \\
99 \\
68 \\
32.4 \\
21.8 \\
22.1 \\
26.4\end{array}$ & $\begin{array}{l}30.4 \\
51 \\
96 \\
66 \\
32.1 \\
21.7 \\
22.0 \\
26.1\end{array}$ & $\begin{array}{l}30.0 \\
50 \\
94 \\
65 \\
31.7 \\
21.6 \\
21.9 \\
25.8\end{array}$ & $\begin{array}{l}29.7 \\
49 \\
92 \\
64 \\
31.5 \\
21.6 \\
21.9 \\
25.6\end{array}$ & $\begin{array}{l}29.4 \\
48 \\
90 \\
63 \\
31.2 \\
21.5 \\
21.9 \\
25.4\end{array}$ & $\begin{array}{l}29.1 \\
48 \\
88 \\
62 \\
31.1 \\
21.5 \\
21.8 \\
25.3\end{array}$ & $\begin{array}{l}29.0 \\
47 \\
87 \\
61 \\
30.9 \\
21.4 \\
21.8 \\
24.9\end{array}$ & $\begin{array}{r}-625 \\
-925 \\
-1,210 \\
-890 \\
-445 \\
-200 \\
-110 \\
-500\end{array}$ \\
\hline $\begin{array}{l}3: 1: 1: 2 \\
5: 1: 2: 3 \\
5: 1: 1: 3 \\
5: 1: 1: 2 \\
4: 3: 2: 2 \\
\end{array}$ & $\begin{array}{l}\mathrm{M}_{2} \mathrm{~S}-\mathrm{MT}-\mathrm{CT} \\
\mathrm{MT}-\mathrm{M}_{2} \mathrm{~S}-\mathrm{M}_{2} \mathrm{ST}-\mathrm{CT} \\
\mathrm{MT}_{2} \mathrm{M}_{2} \mathrm{~T}-\mathrm{M}_{2} \mathrm{~S}-\mathrm{CT} \\
\mathrm{MgO}-\mathrm{M}_{2} \mathrm{~S}-\mathrm{M}_{2} \text { T-CT } \\
\mathrm{MgO}-\mathrm{M}_{2} \mathrm{~S}-\mathrm{CS}-\mathrm{CT}\end{array}$ & $\begin{array}{l}29.0 \\
24.6 \\
25.2 \\
28.6 \\
45\end{array}$ & $\begin{array}{l}27.9 \\
24.2 \\
24.3 \\
27.4 \\
42\end{array}$ & $\begin{array}{l}27.4 \\
23.9 \\
23.9 \\
27.1 \\
41\end{array}$ & $\begin{array}{l}26.9 \\
23.6 \\
23.6 \\
26.5 \\
40\end{array}$ & $\begin{array}{l}26.5 \\
23.4 \\
23.3 \\
26.2 \\
39\end{array}$ & $\begin{array}{l}26.2 \\
23.2 \\
23.1 \\
25.9 \\
38\end{array}$ & $\begin{array}{l}25.9 \\
23.1 \\
22.9 \\
25.6 \\
38\end{array}$ & $\begin{array}{l}25.6 \\
22.9 \\
22.6 \\
25.4 \\
37\end{array}$ & $\begin{array}{l}25.4 \\
22.8 \\
22.5 \\
25.2 \\
37\end{array}$ & $\begin{array}{l}25.2 \\
22.7 \\
22.3 \\
25.0 \\
36\end{array}$ & $\begin{array}{l}24.9 \\
22.6 \\
22.2 \\
24.9 \\
36\end{array}$ & $\begin{array}{l}24.8 \\
22.5 \\
22.0 \\
24.7 \\
35\end{array}$ & $\begin{array}{l}-620 \\
-310 \\
-450 \\
-500 \\
-830\end{array}$ \\
\hline $\begin{array}{l}1: 5: 1: 3 \\
1: 6: 2: 2 \ldots \\
1: 6: 1: 2 \ldots \\
1: 15: 4: 4 \ldots\end{array}$ & $\begin{array}{l}\mathrm{MgO}-\mathrm{CS}-\mathrm{CT}-\mathrm{C}_{3} \mathrm{~T}_{2} \\
\mathrm{MgO}-\mathrm{C}_{2} \mathrm{~S}-\mathrm{CS}-\mathrm{C}_{3} \mathrm{~T}_{2} \\
\mathrm{MgO}-\mathrm{CaO}-\mathrm{C}_{2} \mathrm{~S}_{2}-\mathrm{C}_{3} \mathrm{~T}_{2}\end{array}$ & $\begin{array}{l}47.4 \\
35.1 \\
38.7 \\
30.4\end{array}$ & $\begin{array}{l}46.3 \\
34.5 \\
37.9 \\
30.1\end{array}$ & $\begin{array}{l}45.8 \\
34.2 \\
37.3 \\
30.0\end{array}$ & $\begin{array}{l}45.4 \\
33.9 \\
36.8 \\
29.9\end{array}$ & $\begin{array}{l}45.1 \\
33.7 \\
36.5 \\
29.8\end{array}$ & $\begin{array}{l}44.8 \\
33.5 \\
36.2 \\
29.8\end{array}$ & $\begin{array}{c}\text { (a) } \\
33.4 \\
36.0 \\
29.7\end{array}$ & $\begin{array}{l}33.3 \\
35.8 \\
29.5\end{array}$ & $\begin{array}{l}33.3 \\
35.7 \\
29.3\end{array}$ & $\begin{array}{l}33.2 \\
35.6 \\
28.9\end{array}$ & $\begin{array}{l}33.2 \\
35.5 \\
28.4\end{array}$ & $\begin{array}{l}33.3 \\
(a) \\
28.3\end{array}$ & $\begin{array}{l}-370 \\
-180 \\
-340 \\
-240\end{array}$ \\
\hline
\end{tabular}

a At and above the temperature indicated, the specimen behaved as a semiconductor.

b $\mathrm{A}$ commercial grade of $\mathrm{CaO}$. $\mathrm{TiO}_{2}$ was used in the preparation of the specimen.

- One percent of $\mathrm{Fe}_{2} \mathrm{O}_{3}$ was added to the specimen. 
TABLE 15. Variation of $Q$ value with temperature

\begin{tabular}{|c|c|c|c|c|c|c|c|c|c|c|c|c|c|}
\hline \multirow{2}{*}{ Mole ratio } & \multirow{2}{*}{$\begin{array}{l}\text { Binary join, ternary } \\
\text { field, or quaternary } \\
\text { volume }\end{array}$} & \multicolumn{12}{|c|}{ Value of $Q$ at $1 \mathrm{Mc}$ and- } \\
\hline & & $-50^{\circ} \mathrm{C}$ & $0^{\circ} \mathrm{C}$ & $25^{\circ} \mathrm{C}$ & $50^{\circ} \mathrm{C}$ & $75^{\circ} \mathrm{C}$ & $100^{\circ} \mathrm{C}$ & $125^{\circ} \mathrm{C}$ & $150^{\circ} \mathrm{C}$ & $175^{\circ} \mathrm{C}$ & $200^{\circ} \mathrm{C}$ & $225^{\circ} \mathrm{C}$ & $250^{\circ} \mathrm{C}$ \\
\hline \multicolumn{14}{|c|}{ The system $\mathrm{MgO}-\mathrm{CaO}-\mathrm{TiO}_{2}$} \\
\hline $\begin{array}{l}9: 1: 10 \ldots \\
4: 1: 5 \ldots \\
2: 1: 3 \ldots \\
1: 1: 2 \ldots\end{array}$ & 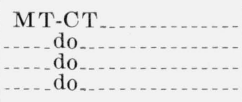 & $\begin{array}{r}5,000 \\
10,000 \\
10,000 \\
10,000\end{array}$ & $\begin{array}{r}5,000 \\
10,000 \\
10,000 \\
10,000\end{array}$ & $\begin{array}{r}3,000 \\
10,000 \\
10,000 \\
10,000\end{array}$ & $\begin{array}{r}5,000 \\
7,000 \\
10,000 \\
10,000\end{array}$ & $\begin{array}{r}5,000 \\
7,000 \\
10,000 \\
10,000\end{array}$ & $\begin{array}{r}3,500 \\
7,000 \\
10,000 \\
10,000\end{array}$ & $\begin{array}{r}3,000 \\
7,000 \\
10,000 \\
4,000\end{array}$ & $\begin{array}{l}2,400 \\
4,000 \\
5,000 \\
4,000\end{array}$ & $\begin{array}{l}1,300 \\
3,000 \\
3,000 \\
3,000\end{array}$ & $\begin{array}{r}650 \\
2,000 \\
1,300 \\
1,200\end{array}$ & $\begin{array}{l}320 \\
900 \\
700 \\
600\end{array}$ & $\begin{array}{l}155 \\
500 \\
340 \\
270\end{array}$ \\
\hline $\begin{array}{l}38: 1: 20 \ldots \\
6: 1: 4 \ldots \\
2: 1: 2 \ldots \\
2: 2: 3 \ldots \\
2: 7: 8 \\
\end{array}$ & \begin{tabular}{c}
$\mathrm{M}_{2} \mathrm{~T}-\mathrm{CT}$ \\
\hdashline do \\
\\
2 do do
\end{tabular} & $\begin{array}{l}10,000 \\
10,000 \\
10,000 \\
10,000\end{array}$ & $\begin{array}{l}10,000 \\
10,000 \\
10,000 \\
10,000\end{array}$ & $\begin{array}{r}8,000 \\
10,000 \\
10,000 \\
7,000 \\
9,000\end{array}$ & $\begin{array}{r}10,000 \\
10,000 \\
10,000 \\
5,000 \\
5,000\end{array}$ & $\begin{array}{l}8,000 \\
7,000 \\
6,000 \\
3,000 \\
4,000\end{array}$ & $\begin{array}{l}8,000 \\
5,000 \\
4,000 \\
2,500 \\
3,000\end{array}$ & $\begin{array}{l}8,000 \\
4,000 \\
3,000 \\
1,800 \\
1,700\end{array}$ & $\begin{array}{l}6,000 \\
3,000 \\
2,200 \\
1,050 \\
1,100\end{array}$ & $\begin{array}{r}4,500 \\
1,650 \\
1,200 \\
530 \\
550\end{array}$ & $\begin{array}{r}2,500 \\
850 \\
530 \\
230 \\
250\end{array}$ & $\begin{array}{r}1,600 \\
440 \\
250 \\
115 \\
120\end{array}$ & $\begin{array}{r}820 \\
210 \\
100 \\
100 \\
50\end{array}$ \\
\hline $\begin{array}{l}4: 1: 1 \ldots \\
2: 1: 1 \\
2: 1: 1 \quad \mathrm{~b} \\
1: 1: 1 \ldots \\
2: 3: 3 \mathrm{~b} \\
1: 2: 2 \\
1: 3: 3 \mathrm{~b}\end{array}$ & 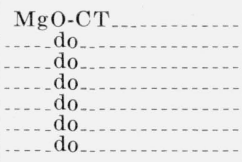 & $\begin{array}{r}10,000 \\
6,000 \\
2,300 \\
7,000 \\
910 \\
7,000 \\
1,800\end{array}$ & $\begin{array}{r}10,000 \\
6,000 \\
2,600 \\
7,000 \\
2,500 \\
7,000 \\
1,800\end{array}$ & $\begin{array}{r}10,000 \\
6,000 \\
4,000 \\
7,000 \\
2,300 \\
7,000 \\
2,300\end{array}$ & $\begin{array}{l}6,000 \\
4,000 \\
2,000 \\
4,000 \\
2,300 \\
3,000 \\
2,200\end{array}$ & $\begin{array}{l}3,000 \\
3,000 \\
1,900 \\
3,000 \\
2,200 \\
2,400 \\
2,200\end{array}$ & $\begin{array}{l}2,300 \\
1,700 \\
1,900 \\
1,700 \\
2,200 \\
1,400 \\
2,100\end{array}$ & $\begin{array}{r}1,300 \\
1,000 \\
1,800 \\
900 \\
2,100 \\
800 \\
2,000\end{array}$ & $\begin{array}{r}700 \\
500 \\
980 \\
500 \\
1,030 \\
420 \\
990\end{array}$ & $\begin{array}{r}330 \\
260 \\
590 \\
230 \\
1,000 \\
230 \\
550\end{array}$ & $\begin{array}{l}160 \\
110 \\
400 \\
104 \\
400 \\
103 \\
380\end{array}$ & $\begin{array}{r}75 \\
60 \\
190 \\
55 \\
160 \\
48 \\
160\end{array}$ & $\begin{array}{l}30 \\
(\mathrm{a}) \\
100 \\
(\mathrm{a}) \\
90 \\
(\mathrm{a}) \\
80\end{array}$ \\
\hline $\begin{array}{l}18: 3: 2 \ldots \\
2: 3: 2 \ldots\end{array}$ & $\mathrm{MgO}-\mathrm{C}_{3} \mathrm{~T}_{2} \ldots$ & $\begin{array}{l}3,000 \\
2,000\end{array}$ & $\begin{array}{l}3,000 \\
2,000\end{array}$ & $\begin{array}{l}2,070 \\
1,470\end{array}$ & $\begin{array}{l}1,670 \\
880\end{array}$ & $\begin{array}{l}1,120 \\
520\end{array}$ & $\begin{array}{l}510 \\
310\end{array}$ & $\begin{array}{l}420 \\
150\end{array}$ & $\begin{array}{l}260 \\
100\end{array}$ & $\begin{array}{r}150 \\
60\end{array}$ & $\begin{array}{l}90 \\
30\end{array}$ & $\underset{(a)}{51}$ & (a) \\
\hline $1: 3: 9$ & $\mathrm{MT}_{2}-\mathrm{CT}-\mathrm{TiO}_{2}$ & $\begin{array}{r}2,200 \\
10,000\end{array}$ & $\begin{array}{r}1,300 \\
1000\end{array}$ & $\begin{array}{l}1,460 \\
900\end{array}$ & $\begin{array}{r}800 \\
700\end{array}$ & $\begin{array}{r}520 \\
800\end{array}$ & $\begin{array}{r}510 \\
1,150\end{array}$ & 1,400 & $\begin{array}{r}100 \\
1,500\end{array}$ & $\begin{array}{r}60 \\
1,700\end{array}$ & $\begin{array}{r}30 \\
1,650\end{array}$ & 1,600 & 1,400 \\
\hline $4: 1: 4 \ldots$ & $\mathrm{MT}-\mathrm{M}_{2} \mathrm{~T}-\mathrm{CT}-$ & 10,000 & 10,000 & 9,000 & 6,500 & 5,000 & 4,000 & 3,000 & 2,500 & 1,700 & 1,000 & 530 & 230 \\
\hline $\begin{array}{l}3: 2: 3 \ldots \ldots \\
2: 3: 1\end{array}$ & $\mathrm{M}_{2} \mathrm{~T}-\mathrm{MgO}-\mathrm{CT}$ & 10,000 & 10,000 & 10,000 & 10,000 & 7,000 & 5,000 & 3,000 & 1,600 & 800 & 370 & 180 & 90 \\
\hline $1: 4: 1 \ldots$ & $\begin{array}{l}\mathrm{MgO}-\mathrm{C}_{3} \mathrm{~T}_{2}-\mathrm{CaO} \\
\mathrm{do}\end{array}$ & $\begin{array}{l}2,000 \\
2,000\end{array}$ & $\begin{array}{l}2,000 \\
1,350\end{array}$ & $\begin{array}{r}1,300 \\
790\end{array}$ & $\begin{array}{l}870 \\
510\end{array}$ & $\begin{array}{l}500 \\
300\end{array}$ & $\begin{array}{l}370 \\
190\end{array}$ & $\begin{array}{l}190 \\
105\end{array}$ & $\begin{array}{r}160 \\
59\end{array}$ & $\begin{array}{l}70 \\
34\end{array}$ & $\begin{array}{l}40 \\
\text { (a) }\end{array}$ & (a) & \\
\hline \multicolumn{14}{|l|}{$\mathrm{M}: \mathrm{C}: \mathrm{S}$} \\
\hline $\begin{array}{l}2: 6: 7 \\
4: 1: 1 \ldots \\
2: 1: 1 \ldots \\
1: 1: 1 \ldots \\
1: 1: 1 \mathrm{e} \\
1: 2: 2 \ldots \\
\end{array}$ & $\begin{array}{l}\mathrm{M}_{2 \mathrm{~S}-\mathrm{CS}} \\
\mathrm{MgO}-\mathrm{CS} \\
\mathrm{d} \\
\text { do } \\
\text { do } \\
\text { do }\end{array}$ & $\begin{array}{r}1,500 \\
7,000 \\
10,000 \\
3,000 \\
2,000 \\
3,000\end{array}$ & $\begin{array}{r}550 \\
4,000 \\
10,000 \\
6,000 \\
1,500 \\
6,000\end{array}$ & $\begin{array}{r}150 \\
4,000 \\
4,000 \\
10,000 \\
2,000 \\
10,000\end{array}$ & $\begin{array}{r}55 \\
7,000 \\
5,000 \\
10,000 \\
2,000 \\
10,000\end{array}$ & $\begin{array}{r}60 \\
7,000 \\
5,000 \\
7,000 \\
1,500 \\
7,000\end{array}$ & $\begin{array}{r}65 \\
7,000 \\
4,000 \\
5,000 \\
1,500 \\
7,000\end{array}$ & $\begin{array}{r}75 \\
7,000 \\
4,000 \\
5,000 \\
1,200 \\
5,000\end{array}$ & $\begin{array}{r}95 \\
7,000 \\
2,500 \\
5,000 \\
800 \\
5,000\end{array}$ & $\begin{array}{r}110 \\
7,000 \\
2,400 \\
5,000 \\
690 \\
4,000\end{array}$ & $\begin{array}{r}130 \\
7,000 \\
2,300 \\
5,000 \\
480 \\
4,000\end{array}$ & $\begin{array}{r}190 \\
7,000 \\
2,200 \\
5,000 \\
370 \\
4,000\end{array}$ & $\begin{array}{r}190 \\
7,000 \\
2,200 \\
5,000 \\
260 \\
4,000\end{array}$ \\
\hline $\begin{array}{l}4: 2: 1^{\mathrm{c}} \ldots \\
2: 2: 1 \\
1: 2: 1^{\mathrm{c}} \ldots\end{array}$ & $\begin{array}{l}\mathrm{MgO}-\mathrm{C}_{2} \mathrm{~S} \\
\quad \mathrm{do} \\
\text { do }\end{array}$ & $\begin{array}{r}440 \\
1,400 \\
1,500\end{array}$ & $\begin{array}{r}260 \\
1,400 \\
1,000\end{array}$ & $\begin{array}{r}240 \\
1,000 \\
800\end{array}$ & $\begin{array}{l}230 \\
950 \\
500\end{array}$ & $\begin{array}{l}240 \\
820 \\
330\end{array}$ & $\begin{array}{l}240 \\
780 \\
200\end{array}$ & $\begin{array}{l}230 \\
780 \\
130\end{array}$ & $\begin{array}{r}220 \\
750 \\
95\end{array}$ & $\begin{array}{r}180 \\
720 \\
65\end{array}$ & $\begin{array}{r}150 \\
720 \\
45\end{array}$ & $\begin{array}{r}110 \\
720 \\
35\end{array}$ & $\begin{array}{r}80 \\
640 \\
25\end{array}$ \\
\hline \multicolumn{14}{|l|}{ C:S:T } \\
\hline $\begin{array}{l}1: 3: 1 \ldots \\
1: 9: 1 \mathrm{c}\end{array}$ & $\begin{array}{l}\mathrm{CT}-\mathrm{SnO}_{2} \ldots \\
\mathrm{do}\end{array}$ & $\begin{array}{r}2,000 \\
20\end{array}$ & $\begin{array}{r}2,000 \\
30\end{array}$ & $\begin{array}{r}620 \\
30\end{array}$ & $\begin{array}{l}680 \\
\text { (a) }\end{array}$ & 880 & 870 & 700 & 570 & 370 & 240 & 150 & 80 \\
\hline $\begin{array}{l}3: 1: 2 \ldots \\
2: 1: 1 \ldots\end{array}$ & $\begin{array}{r}\text { CT-CS } \\
\text { do }\end{array}$ & 3,500 & 3,500 & $\begin{array}{l}6,000 \\
5,600\end{array}$ & 5,000 & $\begin{array}{l}4,000 \\
5,300\end{array}$ & $\begin{array}{l}3,500 \\
3,900\end{array}$ & $\begin{array}{l}2,500 \\
1,900\end{array}$ & $\begin{array}{l}1,650 \\
1380\end{array}$ & $\begin{array}{l}1,300 \\
590\end{array}$ & $\begin{array}{l}870 \\
280\end{array}$ & 400 & 200 \\
\hline $3: 2: 1$ & ....... do & & & $\begin{array}{r}10,000 \\
10,00\end{array}$ & 10,000 & $\begin{array}{r}5,000 \\
10,000\end{array}$ & $\begin{array}{r}5,000 \\
10,00\end{array}$ & $\begin{array}{l}1,900 \\
6,000\end{array}$ & $\begin{array}{l}1,380 \\
6,000\end{array}$ & 3,000 & 1,620 & $\begin{array}{r}140 \\
1,210\end{array}$ & $\begin{array}{r}60 \\
740\end{array}$ \\
\hline $5: 4: 1 \ldots$ & ...... do_. & 9,000 & 9,000 & 7,000 & 7,000 & 7,000 & 7,000 & 5,000 & 4,000 & 4,000 & 4,000 & 2,500 & 2,000 \\
\hline $\begin{array}{l}4: 1: 2^{\circ} \mathrm{-} \\
6: 3: 2^{\circ}-\end{array}$ & $\mathrm{C}_{3} \mathrm{~T}_{2}-\mathrm{CS}_{\ldots}$ & 700 & 500 & 400 & 270 & 220 & 170 & 130 & 100 & 70 & (a) & & \\
\hline $\begin{array}{ll}0: 1: 4 \mathrm{e}^{-} \\
8:-2\end{array}$ & $\mathrm{C}_{3} \mathrm{~T}_{2}-\mathrm{C}_{2} \mathrm{~S}$ & $\begin{array}{l}1,450 \\
1,400\end{array}$ & $\begin{array}{l}860 \\
700\end{array}$ & $\begin{array}{l}620 \\
450\end{array}$ & $\begin{array}{l}380 \\
270\end{array}$ & $\begin{array}{l}290 \\
190\end{array}$ & $\begin{array}{l}200 \\
140\end{array}$ & $\begin{array}{r}150 \\
90\end{array}$ & $\begin{array}{r}110 \\
70\end{array}$ & $\underset{(a)}{85}$ & 55 & (a) & \\
\hline $7: 2: 2 \mathrm{e}-$ & -... do do... & $1,+00$ & 90 & $\begin{array}{r}430 \\
70\end{array}$ & 70 & & & & & & & & \\
\hline $19: 8: 2^{\mathrm{c}} \mathrm{-}$ & $\ldots$.......... & 860 & 370 & 230 & 150 & 100 & 70 & 45 & (a) & & & & \\
\hline $1: 3: 9$ & $\mathrm{CT}-\mathrm{SnO}_{2}-\mathrm{TiO}_{2}$ & 10,000 & 9,000 & 2,000 & 1,900 & 750 & 640 & 580 & 390 & 350 & 200 & 110 & 70 \\
\hline $\begin{array}{l}2: 2: 3 \\
2 \cdot 1: 4\end{array}$ & -.... do do & 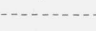 & & 2,400 & 1,900 & 1,400 & 1,400 & 1,300 & 1,300 & 1,300 & 810 & 650 & 350 \\
\hline $3: 2: 2 \mathrm{c}$ & $\mathrm{CT}-\mathrm{CS}-\mathrm{SnO}$ & 1.200 & 750 & 2,600 & 2,500 & 1,900 & 1,800 & 2,200 & 1,700 & 980 & 440 & 220 & 100 \\
\hline $3: 3: 2$ & do & 4,000 & 4,000 & $\begin{array}{l}1,530 \\
1,300\end{array}$ & $\begin{array}{r}1,430 \\
900\end{array}$ & $\begin{array}{r}1,460 \\
620\end{array}$ & $\begin{array}{r}1,140 \\
390\end{array}$ & $\begin{array}{l}890 \\
230\end{array}$ & $\begin{array}{l}660 \\
130\end{array}$ & $\begin{array}{r}370 \\
70\end{array}$ & $\begin{array}{r}220 \\
40\end{array}$ & $\begin{array}{r}140 \\
30\end{array}$ & ${ }_{(\mathrm{a})}^{80}$ \\
\hline $27: 18: 2 \mathrm{c}_{-} \ldots$ & $\mathrm{C}_{3} \mathrm{~T}_{2}-\mathrm{CS}-\mathrm{C}_{2} \mathrm{~S}$ & 850 & 450 & 360 & 210 & 180 & 120 & 90 & 70 & 50 & 35 & 25 & 20 \\
\hline $6: 3: 11^{\mathrm{c}} \ldots$ & do & 1,000 & 610 & 460 & 250 & 220 & 160 & 110 & 75 & 50 & 40 & 25 & 20 \\
\hline \multicolumn{14}{|c|}{ The system $\mathrm{MgO}-\mathrm{CaO}-\mathrm{SnO}_{2}-\mathrm{TiO}_{2}$} \\
\hline $8: 1: 4: 1 \mathrm{~b}$ & $\mathrm{M}_{2} \mathrm{~S}-\mathrm{CT} \ldots$ & 6,000 & 2,000 & 1,200 & 1,100 & 1,000 & 900 & 700 & 600 & 560 & 500 & 400 & 280 \\
\hline $\begin{array}{l}4: 1: 2: 1 \mathrm{~b}-\ldots \\
2: 1: 1: 1\end{array}$ & .....do... do & $\begin{array}{l}4,000 \\
5000\end{array}$ & $\begin{array}{l}1,600 \\
5000\end{array}$ & $\begin{array}{r}900 \\
5000\end{array}$ & $\begin{array}{r}800 \\
5000\end{array}$ & $\begin{array}{r}800 \\
5000\end{array}$ & 1,000 & 1,000 & 1,000 & 1,000 & 1,000 & 800 & 500 \\
\hline $2: 2: 1: 2$ & do & $\begin{array}{l}5,000 \\
3,500\end{array}$ & $\begin{array}{l}2,000 \\
3,500\end{array}$ & $\begin{array}{l}3,000 \\
3,500\end{array}$ & 2,000 & $\begin{array}{r}5,000 \\
4500\end{array}$ & $\begin{array}{r}5,000 \\
4,000\end{array}$ & 4,500 & 2,000 & 1,500 & 870 & 390 & 200 \\
\hline $2: 5: 1: 5 \mathrm{~b}$ & do & 4,000 & 4,000 & 4,000 & $\begin{array}{l}2,000 \\
3,000\end{array}$ & $\begin{array}{l}4,500 \\
3,000\end{array}$ & 4,000 & $\begin{array}{l}3,000 \\
2,000\end{array}$ & $\begin{array}{l}1,400 \\
1500\end{array}$ & 1,000 & 620 & & 190 \\
\hline $2: 9: 1: 9 \mathrm{~b}$ & ...do... & 2,500 & $\begin{array}{l}4,000 \\
2,500\end{array}$ & $\begin{array}{l}4,000 \\
2,500\end{array}$ & $\begin{array}{l}3,000 \\
1,400\end{array}$ & $\begin{array}{l}3,000 \\
1,300\end{array}$ & $\begin{array}{l}3,000 \\
1,300\end{array}$ & $\begin{array}{l}2,000 \\
1,200\end{array}$ & $\begin{array}{r}1,500 \\
910\end{array}$ & $\begin{array}{l}990 \\
590\end{array}$ & $\begin{array}{l}360 \\
380\end{array}$ & $\begin{array}{l}220 \\
200\end{array}$ & $\begin{array}{l}120 \\
110\end{array}$ \\
\hline $2: 1: 1: 2$ & $\mathrm{M}_{2} \mathrm{ST}_{\mathrm{T}} \mathrm{CT} \ldots$ & 2,000 & 1,500 & 2,000 & 1,900 & 1,800 & 1,400 & 1,100 & 870 & 650 & 400 & 230 & 160 \\
\hline & & 780 & 860 & 1,100 & 1,300 & 1,250 & 950 & 760 & 750 & 540 & 400 & 250 & 160 \\
\hline $2: 9: 1: 10^{b} \ldots$ & ..... do... & 2,000 & 2,000 & 3,000 & 3,000 & 2,000 & 990 & 970 & 400 & 280 & 180 & 110 & 70 \\
\hline $1: 3: 1: 2 b_{\ldots} \ldots$ & $\mathrm{MgO}-\mathrm{CT}-\mathrm{CS}_{-}$ & 2,000 & 2,000 & 3,000 & 3,000 & 2,000 & 2,000 & 2,000 & 1,600 & 1,300 & 800 & 410 & 200 \\
\hline $2: 2: 1: 1 \mathrm{c} \ldots$ & do & 3,000 & 3,000 & 3,000 & 2,700 & 1,800 & 1,300 & 860 & 570 & 360 & 240 & $\begin{array}{l}410 \\
160\end{array}$ & $\begin{array}{r}200 \\
90\end{array}$ \\
\hline & .... do & 6,000 & 6,000 & 4,000 & 3,000 & 2,900 & 2,300 & 1,600 & 1,400 & 1,300 & 1,100 & 700 & 500 \\
\hline $2: 5: 4: 1$ & $\ldots$ do & 5,000 & 5,000 & 5,000 & 2,000 & 1,500 & 1,300 & 1,000 & 1,200 & 1,100 & 820 & 660 & 450 \\
\hline $2: 2: 2: 1$ & $\mathrm{M}_{2} \mathrm{~S}-\mathrm{CT}-\mathrm{CS}$ & 1,800 & 570 & 1,390 & 2,750 & 2,700 & 2,670 & 2,630 & 1,740 & 1,410 & 1,280 & 1,270 & 1,080 \\
\hline $\begin{array}{l}3: 1: 1: 2 \ldots \\
5: 1: 23\end{array}$ & $\begin{array}{l}\mathrm{M}_{2} \mathrm{~S}-\mathrm{MT} \text { T-CT } \\
\text { MTT-M S-M ST-CT }\end{array}$ & $\begin{array}{l}6,000 \\
1400\end{array}$ & 6,000 & 6,000 & 6,000 & 6,000 & 3,000 & 2,500 & 1,900 & 1,100 & 550 & 340 & 230 \\
\hline $5: 1: 1: 3$ & $\mathrm{MT}-\mathrm{M}_{2} \mathrm{~T}-\mathrm{M}_{2} \mathrm{~S}-\mathrm{CT}$ & $\begin{array}{l}1,400 \\
5,000\end{array}$ & $\begin{array}{l}1,400 \\
5000\end{array}$ & $\begin{array}{l}1,400 \\
5,000\end{array}$ & 1,900 & 1,900 & 1,900 & 1,300 & 950 & 630 & 340 & 210 & 130 \\
\hline $5: 1: 1: 2 \ldots$ & $\mathrm{MgO}-\mathrm{M}_{2} \mathrm{~S}-\mathrm{M}_{2} \mathrm{~T}-\mathrm{CT}$ & 1,600 & 2,400 & $\begin{array}{r}5,000 \\
930\end{array}$ & $\begin{array}{l}500 \\
910\end{array}$ & $\begin{array}{r}5,000 \\
810\end{array}$ & $\begin{array}{r}2,500 \\
760\end{array}$ & $\begin{array}{r}2,500 \\
720\end{array}$ & $\begin{array}{r}1,600 \\
680\end{array}$ & $\begin{array}{l}930 \\
560\end{array}$ & $\begin{array}{l}660 \\
400\end{array}$ & $\begin{array}{l}330 \\
270\end{array}$ & $\begin{array}{l}210 \\
170\end{array}$ \\
\hline $4: 3: 2: 2 \ldots$ & $\mathrm{MgO}-\mathrm{M}_{2} \mathrm{~S}-\mathrm{CS}-\mathrm{CT}$ - & 2,300 & 2,200 & 1,900 & 3,000 & 2,100 & 2,000 & 1,530 & 1,030 & 690 & 350 & 200 & 100 \\
\hline $\begin{array}{l}1: 5: 1: 3 \ldots \\
1: 6: 2: 2 \ldots\end{array}$ & $\begin{array}{l}\mathrm{MgO}-\mathrm{CS}-\mathrm{CT}-\mathrm{C}_{3} \mathrm{~T}_{2 \ldots} \ldots \\
\mathrm{MgO}-\mathrm{C}_{2} \mathrm{~S}-\mathrm{CS}-\mathrm{C}_{3} \mathrm{~T}_{2 \ldots}\end{array}$ & $\begin{array}{l}590 \\
760\end{array}$ & $\begin{array}{l}350 \\
560\end{array}$ & $\begin{array}{l}260 \\
440\end{array}$ & $\begin{array}{l}100 \\
250\end{array}$ & $\begin{array}{r}70 \\
210\end{array}$ & $\begin{array}{r}60 \\
170\end{array}$ & (a) & 120 & 95 & 65 & 40 & 25 \\
\hline $1: 6: 1: 2 \ldots$ & $\mathrm{MgO}-\mathrm{CaO}-\mathrm{C}_{2} \mathrm{~S}^{-\mathrm{C}_{3} \mathrm{~T}_{2-}}$ & 1,100 & 890 & 830 & 580 & 400 & 380 & $\begin{array}{l}100 \\
260\end{array}$ & 170 & $\begin{array}{r}95 \\
100\end{array}$ & $\begin{array}{l}00 \\
70\end{array}$ & 30 & $(\mathrm{a})$ \\
\hline $1: 15: 4: 4$ & do & 240 & 80 & 60 & 36 & 33 & 31 & 31 & 31 & 33 & 34 & 35 & 24 \\
\hline
\end{tabular}

a See footnote a at end of table 14

b See footnote b at end of table 14

- See footnote $c$ at end of table 14 


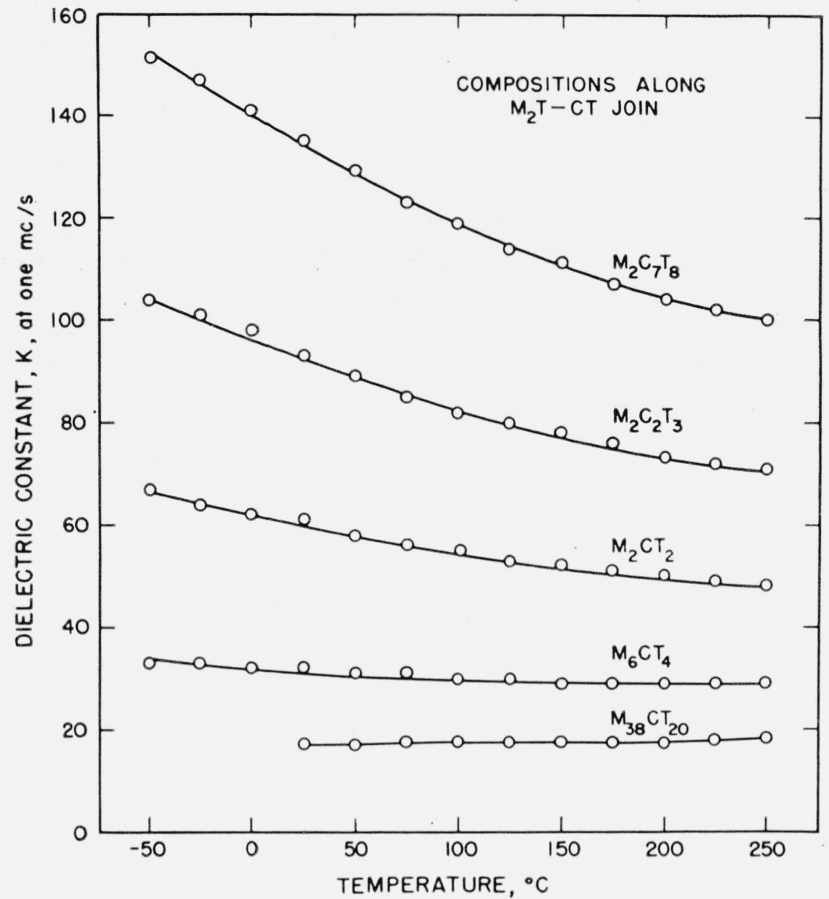

Figure 9. Effect of temperature variations on the dielectric constant of specimens along the $\mathrm{M}_{2} \mathrm{~T}-\mathrm{CT}$ join.

especially along the $\mathrm{MgO}-\mathrm{CT}$ join, when high-purity batch materials were used. Three specimens on the $\mathrm{MgO}-\mathrm{CT}$ join were prepared with a commercialgrade perovskite, replacing the high-purity components usually used. Their maturing temperature was lowered more than $200^{\circ} \mathrm{C}$ by this change in components.

The dielectric properties of specimens on the binary joins were found to undergo a regular change with variations in the proportions of the end members. This change is illustrated in figure 9 for the dielectric constant, which varied from about 15 to about 165 , depending on the compositions. The use of commercial-grade components caused a slight decrease in these values, together with the lowered maturing temperatures. The $Q$-values were good in all parts of the system, being, with a few exceptions, between 500 and 10,000 .

Along the MT-CT, $\mathrm{M}_{2} \mathrm{~T}-\mathrm{CT}$, and $\mathrm{MgO}-\mathrm{CT}$ joins, the temperature coefficient of dielectric constant $(T C K)$ varied in a regular fashion as the composition was changed along the join (see fig. 9, in which this behavior is illustrated). It was found to be strongly negative near the CT end of the joins, and to approach zero or positive values as the percentage of $\mathrm{CT}$ in the specimen approached zero.

For specimens along the $\mathrm{MgO}-\mathrm{C}_{3} \mathrm{~T}_{2}$ join, the $T C K$ values were irregular, showing shallow minima, and the values were numerically small.

\subsection{The System $\mathrm{MgO}-\mathrm{CaO}-\mathrm{SnO}_{2}$}

The results of the dielectric tests on specimens from this system are listed in tables 13, 14, and 15 . Specimens of these compositions are characterized by low $K$-values, high $Q$-values, and by a positive

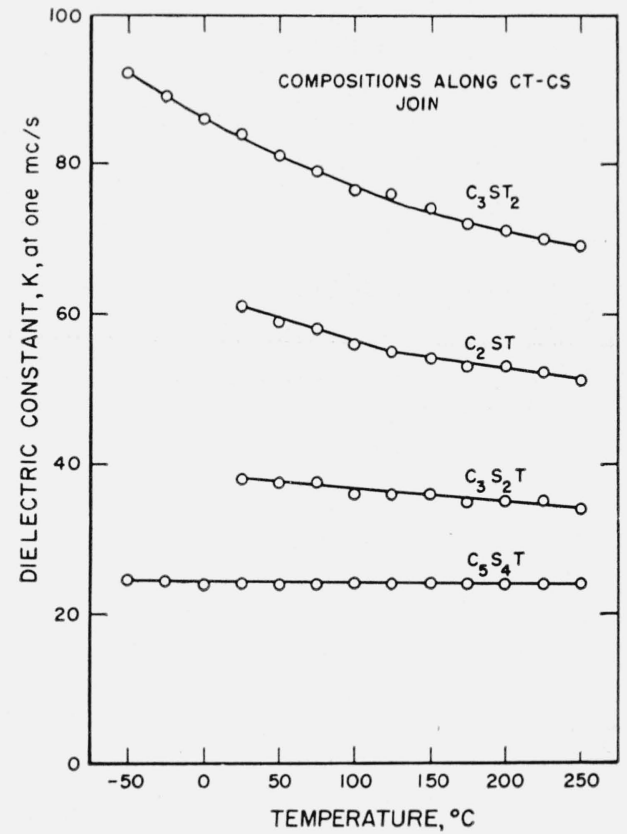

FIgURE 10. Effect of temperature variations on the dielectric constant of specimens along the CT-CS join.

temperature coefficient of $K$ throughout the system.

Specimens along the $\mathrm{MgO}-\mathrm{CS}$ join are noteworthy for the fact that they maintain a Q-value of several thousand, at temperatures as high as $250^{\circ} \mathrm{C}$.

In some cases 1 percent of $\mathrm{Fe}_{2} \mathrm{O}_{3}$ was added as an aid in securing matured specimens. This additive was found to have the undesirable effect of lowering the Q-value, particularly at the higher temperatures.

\subsection{The System $\mathrm{CaO}-\mathrm{SnO}_{2}-\mathrm{TiO}_{2}$}

The dielectric properties of specimens from this system are given in tables 13,14 , and 15 . Maturing temperatures varied from $1,400^{\circ}$ to $1,550^{\circ} \mathrm{C}$, depending on the composition. In a number of cases the use of a 1-percent addition of $\mathrm{Fe}_{2} \mathrm{O}_{3}$ as a flux or mineralizer was required in order to obtain matured specimens. The same effect probably could have been achieved by using less pure com. ponents.

Table 13 shows that the value of $K$ changes regularly along the binary joins as the specimen composition changes from that of one end member to the other. The highest value of $K$ noted was about 165 for the compound $\mathrm{CaO} \cdot \mathrm{TiO}_{2}$. The lowest values noted were 12 and 14 for the compounds $\mathrm{C}_{2} \mathrm{~S}$ and $\mathrm{CS}$, respectively. No regular variation was noted in the ?-values. It may be observed, however, that these values were generally higher on joins having $\mathrm{CT}$ as an end member than they were on joins having $\mathrm{C}_{3} \mathrm{~T}_{2}$ as an end member. This difference was probably due to the presence of $\mathrm{Fe}_{2} \mathrm{O}_{3}$ in the specimens on the latter joins.

Data concerning the variation of $K$ and $Q$ with temperature are listed in tables 14 and 15 . On the binary joins, there was a regular variation of the temperature coefficient of $K$ with composition. For example, see figure 10. A few specimens showed a 
small negative $T C K$, and two specimens had a positive value. It is thought that not too much significance should be attached to the positive values and the smaller negative ones, as the specimens were semiconductors at the higher temperatures. This lower value may be caused by the $\mathrm{Fe}_{2} \mathrm{O}_{3}$ additive in these specimens.

\subsection{The System $\mathrm{MgO}-\mathrm{CaO}-\mathrm{SnO}_{2}-\mathrm{TiO}_{2}$}

The dielectric properties of the specimens in the quaternary system are about as would be expected from a knowledge of the ternary subsystems and from the knowledge that there are no quaternary compounds formed. The solid-solution development seems to result in an averaging of the properties of the compounds existing in the system. The results of the tests are listed in tables 13, 14, and 15.

The structure of the compound $\mathrm{C}_{3} \mathrm{~T}_{2}$ seems to be very sensitive to small quantities of impurities. It was observed that the introduction of small amounts of $\mathrm{MgO}$ and $\mathrm{C}_{2} \mathrm{~S}$ into the $\mathrm{C}_{3} \mathrm{~T}_{2}$ lattice caused very pronounced changes in the diffraction pattern of the material. The structural change seemed to be from a probable monoclinic symmetry to a very close approach to a cubic-perovskite symmetry, without, however, appreciable changes in the dielectric properties of the material.

\section{Summary}

A study of solid-state reactions in the system $\mathrm{MgO}-\mathrm{CaO}-\mathrm{SnO}_{2}-\mathrm{TiO}_{2}$ and its subsystems has been conducted. The results have either substantiated or shown that there exist in the system eight binary compounds, one ternary compound, and no quaternary compounds. Compatibility relations have been established for each of the four ternary subsystems and for the quaternary system. Extensive solidsolution formation was noted.
Dielectric-test samples were prepared and tested in each system except the system $\mathrm{MgO}-\mathrm{SnO}_{2}-\mathrm{TiO}_{2}$, from which matured specimens were not obtained. Maturing temperatures were, in general, higher than $1,500^{\circ} \mathrm{C}$. Values of the dielectric constant varied between 12 and 165, depending upon the composition of the specimen. For most samples tested, the temperature coefficient of $K$ was negative, although the system $\mathrm{MgO}-\mathrm{CaO}-\mathrm{SnO}_{2}$ is characterized by positive values. Values for $Q$ of several thousand were found for most of the specimens studied. A number of test pieces maintained high $Q$-values at temperatures as high as $250^{\circ} \mathrm{C}$.

\section{References}

[1] R. Rieke and A. Ungewiss, Ber. deut. keram. Ges. 1\%, 237 (1936)

[2] George R. Shelton, Ansel S. Creamer, and Elmer N. Bunting, J. Research NBS 41, 17 (1948) RP1899.

[3] Elmer N. Bunting, George R. Shelton, and Ansel S. Creamer, J. Research NBS 43, 237 (1949) RP2025.

[4] C. Schusterius, Z. tech. Phys. 16, 640 (1935).

[5] E. J. W. Verwey and J. M. Stevels, U. S. Patent 2,534,390 (December 1950)

[6] Eugene Wainer, U. S. Patents 2,402,515 (June, 1946), 2,399,082 (April, 1946), 2,402,518 (June, 1946), and 2,452,532 (October, 1948).

[7] William W. Coffeen, J. Am. Ceram. Soc. 36, 207 (1953).

[8] Wilfrid R. Foster, Bull. Am. Ceram. Soc. 30, 291 (1951).

[9] S. M. Lang and R. F. Geller, J. Am. Ceram. Soc. 34, 193 (1951).

[10] L. W. Coughanour and V. A. DeProsse, J. Research NBS 51, 85 (1953) RP2435.

[11] L. W. Coughanour, R. S. Roth, and V. A. DeProsse, J. Research NBS 52, 37 (1954) RP2470.

[12] H. D. Megaw, Acta Cryst. 7, 187 (1954).

[13] G. A. Rankin and H. E. Merwin, J. Am. Chem. Soc. 38, 571 (1916)

[14] Y. Tanaka, J. Chem. Soc. Japan 61, 1023 (1940).

[15] Y. Tanaka, J. Chem. Soc. Japan 62, 199 (1941).

WAshington, July 21, 1954. 